Food losses and waste in primary production

Data collection in the Nordic countries

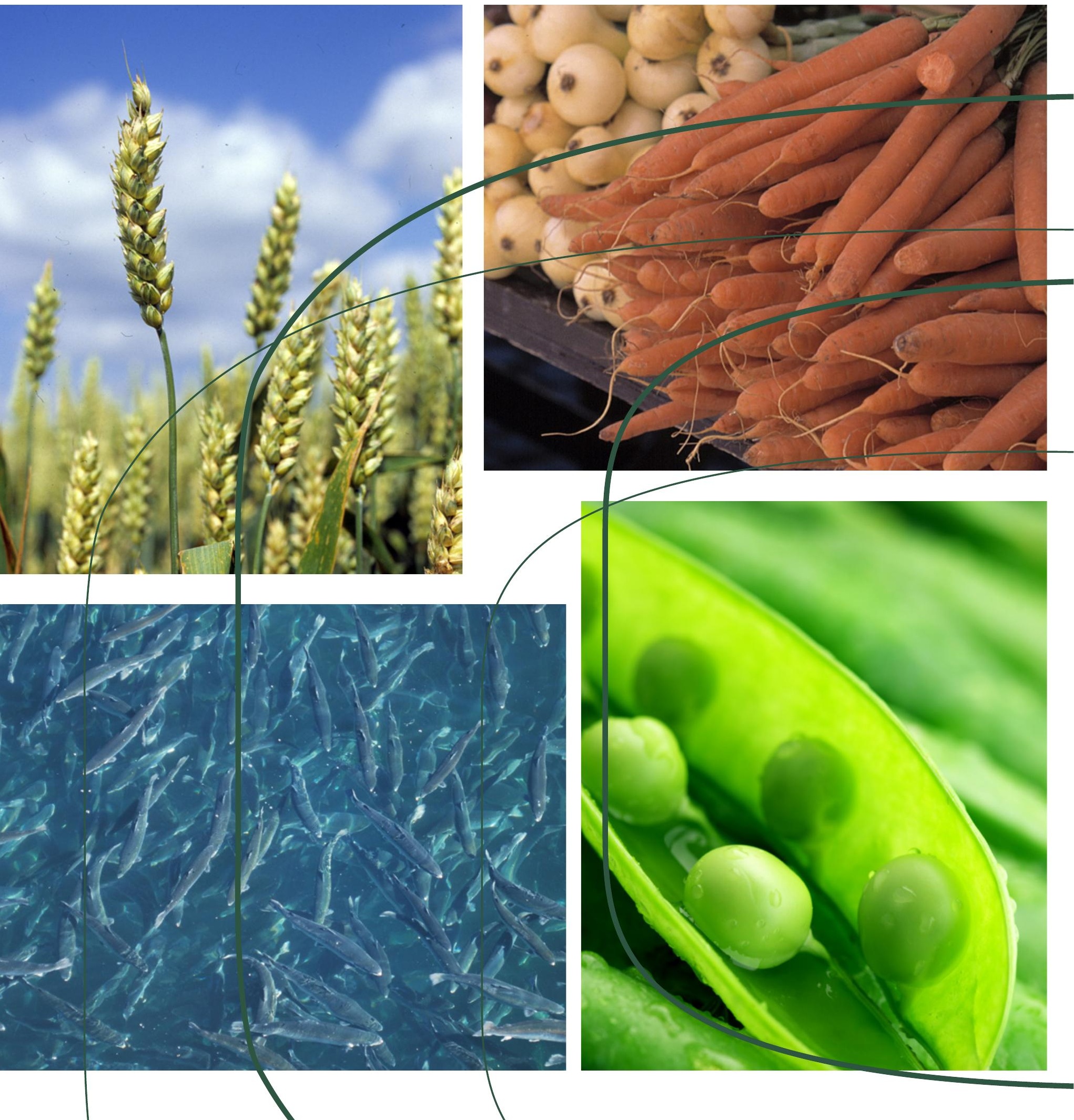







\section{Food losses and waste in primary production}

Data collection in the Nordic countries

Ulrika Franke, Hanna Hartikainen, Lisbeth Mogensen and Erik Svanes

TemaNord 2016:529 
Food losses and waste in primary production

Data collection in the Nordic countries

Ulrika Franke, Hanna Hartikainen, Lisbeth Mogensen and Erik Svanes

ISBN 978-92-893-4609-2 (PRINT)

ISBN 978-92-893-4610-8 (PDF)

ISBN 978-92-893-4611-5 (EPUB)

http://dx.doi.org/10.6027/TN2016-529

TemaNord 2016:529

ISSN 0908-6692

(C) Nordic Council of Ministers 2016

Layout: Hanne Lebech

Cover photo: Shutterstock; Swedish Board of Agriculture; Urban Wigert; Per G Norén

Print: Rosendahls-Schultz Grafisk

Printed in Denmark

This publication has been published with financial support by the Nordic Council of Ministers. However, the contents of this publication do not necessarily reflect the views, policies or recommendations of the Nordic Council of Ministers.

www.norden.org/nordpub

Nordic co-operation

Nordic co-operation is one of the world's most extensive forms of regional collaboration, involving Denmark, Finland, Iceland, Norway, Sweden, and the Faroe Islands, Greenland, and Åland.

Nordic co-operation has firm traditions in politics, the economy, and culture. It plays an important role in European and international collaboration, and aims at creating a strong Nordic community in a strong Europe.

Nordic co-operation seeks to safeguard Nordic and regional interests and principles in the global community. Common Nordic values help the region solidify its position as one of the world's most innovative and competitive.

\section{Nordic Council of Ministers}

Ved Stranden 18

DK-1061 Copenhagen K

Phone (+45) 33960200

www.norden.org 


\section{Contents}

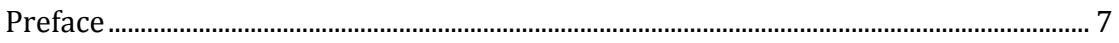

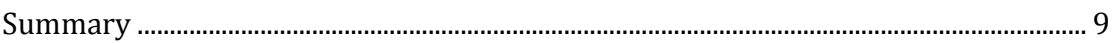

Multi-purpose project .......................................................................................................... 9

Holistic approach to primary production ..................................................................... 9

Introducing the new term side flow ……...............................................................

Comparing different definitions...................................................................................10

Methods used for quantification..............................................................................11

Amounts of side flows and food waste.....................................................................11

1. Introduction..........................................................................................................................13

1.1 Purpose and objectives of the project...............................................................13

1.2 Research questions.......................................................................................13

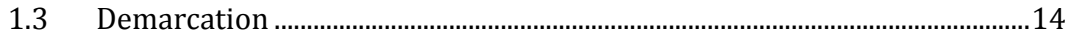

1.4 Reading instructions .......................................................................................14

2. Definitions, terms and system boundaries...............................................................17

2.1 Definitions, terms and system boundaries of this project............................17

2.2 Comparing the definition used in this project to other existing

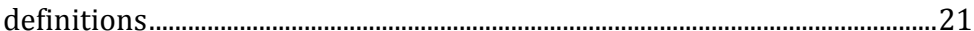

3. Amount of side flows in Nordic countries ..........................................................25

3.1 Food production and conversion factors.......................................................26

3.2 Side flow and food waste....................................................................................28

3.3 Discussion of side flows and food waste.........................................................4

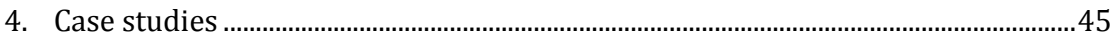

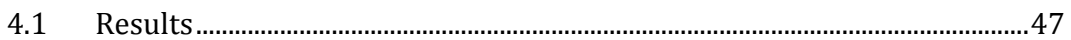

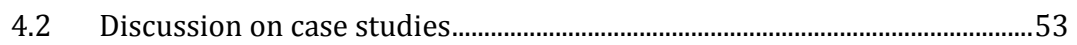

5. Development of methodology .................................................................................5

$5.1 \quad$ Approach for side flow quantification ...........................................................59

5.2 Methods for side flow studies ………...........................................................5

5.3 Choice of methods for side flow quantification .............................................60

5.4 Development of methods ..............................................................................64

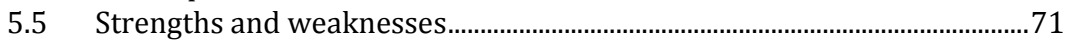

5.6 Research method recommendations ..............................................................75

Conclusions and recommendations .....................................................................................79

Use side flow for a holistic approach in primary production ...................................79

800,000 tonnes of side flows and 330,000 tonnes of food waste............................79

Use more than one method to quantify side flow....................................................80

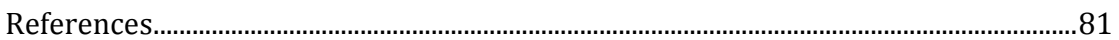




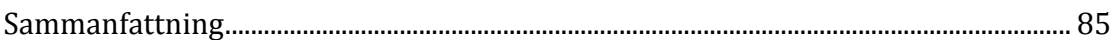

Ett projekt med flera syften ....................................................................................... 85

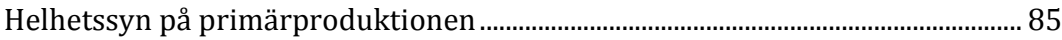

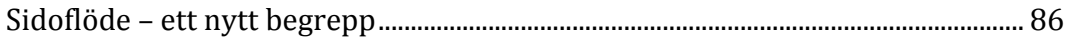

En jämförelse mellan olika terminologier................................................................... 86

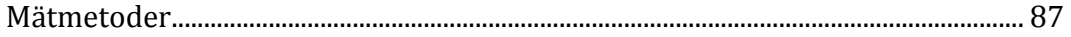

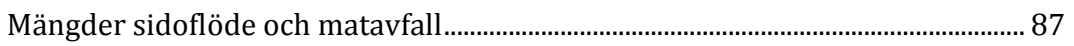

Appendix: Uncertainties of the results......................................................................... 89

Two major issues limit the use of the results of the questionnaires..................... 89 


\section{Preface}

We need to tackle food loss and waste as this is one important factor for achieving sustainable development!

Though it is difficult to develop strategies for preventing food loss and waste if you lack insight into how much, why, and where foodstuff are removed from the food supply chain. Over the past two years two international initiatives were started to develop a manual for measuring food loss and waste. One focuses on measuring the total amount of food waste on a national level within the EU. The other one is a global accounting and reporting standard which enables a wide range of entities to account for and report how much food loss and waste is created and to identify where it occurs.

Evidently there is lack of data on food loss and waste within the primary production sector, and the standards above do not cover all aspects of primary production. This report focuses purely on measuring food loss and waste within primary production and works as a complement to these two initiatives by presenting a framework for definitions and methods for quantification in primary production, including animal rearing. This report also presents a rough estimate of food loss and waste quantities in primary production in the Nordic countries. The project is financed by the Nordic Council of Ministers through the Nordic Green Growth Program.

The project group consists of Ulrika Franke from the Swedish Board of Agriculture, Hanna Hartikainen from the National Resources Institute in Finland, Erik Svanes from Ostfold Research in Norway and Jesper Sørensen from the Danish Agrifish Agency. Researchers Marie Olsson and Staffan Andersson from the Swedish University of Agricultural Sciences, Lisbeth Mogensen from Aarhus University in Denmark, Erling Stubhaug from Ostfold Research in Norway and Raija Räikkönen from the National Resources Institute in Finland have also contributed to the project.

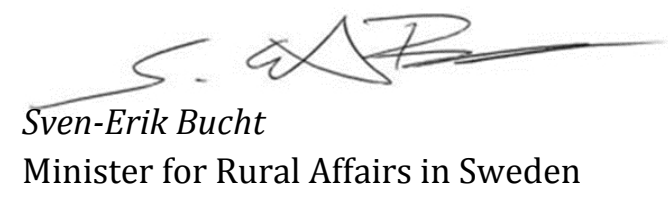





\section{Summary}

This project has resulted in a suggested definitional and methodological framework for future studies of food losses and waste in primary production. It has also resulted in a first attempt to quantify food losses and waste in primary production in the Nordic countries. This study was a pioneering study and requires further improvements as there are large uncertainties in the data presented.

\section{Multi-purpose project}

One purpose of this project has been to test adequate methods for collecting data on food losses and waste from primary producers in the Nordic countries. Another purpose was to estimate the amount of food losses and waste in primary production in the Nordic Countries. In order to collect data and quantify food losses and waste in primary production it was necessary to work on these definitions or possibly introduce new, more useful terms. Thus this project involved defining terms, developing methodologies and quantifying data.

\section{Holistic approach to primary production}

This project was focused on primary production in the Nordic countries of Denmark, Finland, Norway and Sweden. To create a comprehensive picture of food losses and waste in primary production, we conducted a literature study and several case studies. For the methodology development we focused on seven -products to study: carrot, onion, wheat, rye, green peas, field peas and farmed rainbow trout/char.

Primary production in this context refers to the production of agricultural and horticultural products as well as wild berries, wild game, fishery and aquaculture. In order to get a more holistic picture of the primary production sector we also measured losses that occur during animal rearing. An even more holistic approach would also include the growth phases of plants, but due to limited resources we chose to exclude that. 
The chosen system boundary in this project is:

- when cultivated crops, fruit and berries are mature for harvest, wild fruit and berries are harvested, domesticated animals are born and farmed fish are hatched, wild animals or fish are caught, milk when it is drawn from animals, and eggs when laid

- before the primary products enter the next step of the food chain (slaughter, retail or processing).

\section{Introducing the new term side flow}

In this project we introduced the term side flow to capture the flows of food waste and production losses in primary production that were meant to be eaten by humans but never entered the food chain. By side flow we mean:

- Primary products that are intended to be consumed by humans, therefore planned feed production for animals is excluded.

- The parts of primary products that are intended to be eaten by humans, thus peels and bones are excluded.

\section{Comparing different terms}

We have compared three different terms for food waste, developed by three different initiatives:

- Side flow - introduced within this project.

- Food waste - used by the EU project FUSIONS.

- Food Losses and Waste (FLW) - used by the research institute WRI.

Depending on the scope of the quantification, one of the three is preferable. The new term side flow is preferable when understanding the amount and driving forces of the flows of food waste and production losses in primary production from a food security ${ }^{1}$ point-of-view. Neither WRI nor FUSIONS include the rearing phase of animals (or the growth phase of plants) in their scope.

${ }^{1}$ According to the WHO food security exists when all people at all times have access to sufficient, safe, nutritious food to maintain a healthy and active life. 


\section{Methods used for quantification}

Method development was done through case studies of the seven chosen products: carrot, onion, wheat, rye, green peas, field peas and farmed rainbow trout/char. The methods used in the case studies were questionnaires, interviews, direct in-field measurements and published data. The suitability of the used method depends on the product and the needs for the study. Thus we cannot recommend one single quantification method.

Questionnaires are the recommended method in cases where side flow data is known by the primary producers, but is not publicly available, e.g. for most plant crops.

Interviews are the recommended method when the number of participants is small. Interviews are a valuable tool to support other methods. They help achieve a better understanding of side flow reasons and other issues connected with side flows.

Direct measurement of harvest side flows is the recommended method to use in cases where side flows have not been previously measured. In cases where the variability is high, e.g. for field crop harvest side flows, a large number of measurements is necessary in order to attain statistically valid results.

Published data is a good method for calculating side flows where statistical data is available, e.g. for cereal or meat side flows. However, in most cases more information is required for a quantification study.

\section{Amounts of side flows and food waste}

We made a rough estimate of the total amount of side flows in primary production in Finland, Sweden, Norway and Denmark using the definition and system boundaries from this project. Additionally, we calculated food waste in primary production in the four countries using the FUSIONS definition and system boundaries. The side flow and food waste estimates are based on the studies made in this project and existing literature.

The total Nordic amount of side flows in primary production is estimated to be about 0.8 million tonnes and an additional 0.1 million tonnes from animal rearing. This corresponds to 3.2 and $0.5 \%$ of the total production of 24 million tonnes of edible primary products. Using the more narrow food waste and primary production definitions proposed by the EU research project FUSIONS, the food waste amount was estimated to 0.33 million tonnes, or $1 \%$ of the total primary production. The main difference is that food that was planned for food, but ends up as feed is included in the 
side flow amounts, but not in the food waste definition of FUSIONS. Additionally, FUSIONS include inedible parts (such as peels and bones) of food waste whereas we exclude these parts from the side flow. However, the available data on side flows and food waste from primary production is scarce and the uncertainties of the available data are significant.

It is important to note that the side flow and food waste amounts are rough estimates of the Nordic figures and do not consider country-specific circumstances. Thus there is need to get a better understanding of product and country-specific side flow and food waste amounts to improve the current estimates. 


\section{Introduction}

The importance of reducing food losses and waste has become a major topic at national, international and global levels and is high on the agenda for FAO, OECD and EU. The UN Sustainability Development Goal 12.3 and the EU Circular Economy Package are two recent initiatives towards less wasteful food production and consumption. Food losses and waste include the waste of resources such as water, land use and energy and lead to an unnecessary impact on the environment as well as the unnecessary emissions of greenhouse gases. Food losses and waste are also a food security issue, and in order to feed a growing population our resources need to be used wisely. Last but not least food losses and waste may cause an economic loss for the actors involved, and this may in fact serve as an incentive for reduction.

\subsection{Purpose and objectives of the project}

One purpose of this project has been to test adequate methods for collecting data on food losses and waste from primary producers in the Nordic countries. Another purpose was to try to estimate the amount of food losses and waste in primary production in the Nordic Countries. In order to collect data and quantify food losses and waste in primary production it was necessary to work on these definitions or possibly introduce new, more useful terms. Thus this project involved defining terms, developing methodologies and quantifying data.

\subsection{Research questions}

The research questions in this project can be summarised as follows:

- How can food losses and waste in the primary production sector be defined?

- How can the system boundaries of the primary production sector be set, when the aim is to quantify and ultimately reduce food losses and waste? 
- What term can be used instead of food losses or food waste considering the fact that raw materials produced in the sector are not always defined as food, nor is it considered waste as in waste handling?

- What are the best methods to use when quantifying food losses and waste in the primary production sector, and how should these methods be adapted to obtain the most reliable and precise data?

- What are the amounts of food losses and waste in the primary production sector in the Nordic countries on a yearly basis?

\subsection{Demarcation}

Food losses and waste occur in all parts of the food supply chain. ${ }^{2}$ In this project we are focusing on primary production in the Nordic countries of Denmark, Finland, Norway and Sweden. In order to get a holistic picture of the primary production sector we have also included animal rearing in the scope. An even more holistic approach would be to include the growth stages of plants, but we have decided against this.

We have included all primary product in the comprehensive side flow and food waste study (Chapter 3), through using results from this study as well as data from scientific publications and expert knowledge. However, for the methodology development we focused on seven products: carrot, onion, wheat, rye, field peas, green peas and farmed rainbow trout/char. Furthermore, we do not include "non-physical" losses and waste in our scope, but focus only on the realised yield and its uses. Examples of nonphysical side flows are when the crop yield is lower than expected or when the milk production is lower than in an optimal situation.

\subsection{Reading instructions}

Overall this is a methodology study rather than a quantification study although we have presented the data collected during the methodology development.

Chapter 2 aims to introduce a term for food losses and waste which is more applicable to the whole primary productions sector in the context of food security, since it includes animal rearing. It is also an attempt to

2 The food supply chain is the connected series of activities used to produce, process, distribute and consume food, e.g. animal feed production is not included while it is often used as an input for the food supply chain. 
compare this approach with two newly introduced definitions, namely from the FUSIONS Definitional Framework for Food Waste (Fusions report) (Östergren et al., 2014) and from the Food Loss and Waste Accounting and Reporting Standard (FLW Standard) (WRI 2016). This chapter is an introduction to the primary production sector. Side flow studies can have a wide range of objectives and cover different scopes. It is up to the user of this report to choose what definition, terms and system boundary best serves his/her purposes.

In Chapter Three we present a rough estimate of data on total food losses and waste in primary production for Finland, Sweden, Norway and Denmark using our system boundaries and definitions. The estimates are based on the studies conducted as part of this project and from existing literature. We also present results using the system boundaries and definitions of FUSIONS.

In Chapter 4 we present the results and findings from the questionnaires and field studies conducted as part of this project. Chapter 5 is a description of different research methods that may be used for quantification of food losses and waste in primary production, and we share our experience from the project. In this chapter we also discuss our overall findings regarding data collection methods and give further recommendations for the suitable methods to estimate food losses and waste in primary production. In Chapter 6 we give our final conclusions.

Each part of the project (definitions, methodology and quantifications) is described separately, and general conclusions covering all parts are found in Chapter Six, which also includes the overall conclusions and recommendations. 



\section{Definitions, terms and system boundaries}

In order to get a holistic approach of primary production we have proposed the term side flow instead of food loss or food waste. We define side flow in primary production as:

- Primary products ${ }^{3}$ that were intended to be eaten by human.

- The parts of food that are expected to be consumed, thus inedible parts of food e.g. peels and bones are excluded.

- Crops, fruit and berries that are mature for harvest, wild fruit and berries at the time of harvest, domesticated animals from birth, wild animals when they are caught or killed, milk that is drawn from animals, eggs which are laid, wild fish/shellfish when caught, farmed fish from hatching.

- Primary products that are removed from the food supply chain ${ }^{4}$ before they enter the next step of the food supply chain (e.g. slaughter, retail, processing).

In Chapter 3 we present the side flow of rearing phase separate from rest of the side flow (see further discussion in the end of Subchapter 2.1).

\subsection{Definitions, terms and system boundaries of this project}

One of the main purposes of this study was to get an understanding of food waste in primary production to supplement estimates of food waste in other steps of the food supply chain: processing, retail, restaurants and households. However, primary production is significantly different from

\footnotetext{
${ }^{3}$ Goods which are available from cultivating raw materials without a manufacturing process. 4 The food supply chain is the connected series of activities used to produce, process, distribute and consume food, e.g. animal feed production is not included while it is often used as an input for food supply chain.
} 
other steps of the food supply chain, and due to these differences there are several challenges to define food waste in primary production.

To capture the challenges in both animal and plant production at farm level, we proposed using the term "side flow" instead of the term "food waste". The main reasons behind this choice are:

- Problem with using the term "food": The term "food waste" is often understood as "food that was removed from the food supply chain but could have been consumed by humans had it been stored or prepared differently". However, in primary production it is difficult to draw a line between which parts of the production are suitable for human consumption and which parts are not suitable, for example when the product has spoilt in the field. The term side flow solves this problem.

- Problem with using the terms "waste" and "loss": Primary production (in comparison to other steps of food supply chain) is subjected to occurrences which are beyond the farmers' control, such as weather conditions. This means that this type of waste can be hard to avoid. In contrast, food waste in the latter part of the food supply chain is more often caused by deliberate actions taken by people and are therefore more avoidable. For instance, this is recognised in the HLPE-report (HLPE 2014), and they proposed the term "food waste" to reflect "behavioral/voluntary/result of a choice" wasting actions that usually take place at consumer level; whereas, in the HLPE-report "non-behavioral/non-voluntary/nonresult-of -a-choice food waste" is called "food loss" which takes place prior to consumer level. Producers do not identify with the terms "waste" and "loss" since it alludes to mistakes and wasteful behaviour. Also, side flow in most cases is not "wasted" or "lost" but used for a beneficial purpose at the farm, such as animal feed. Finally, even in English "food loss" is relatively close to the term "food waste", and people can easily mix-up these two terms. Therefore, we wanted to introduce a completely different term that cannot be easily mixed with the "food waste"-term. Using the term side flow solves this problem. 
Figure 1: Terms and system boundaries of this project

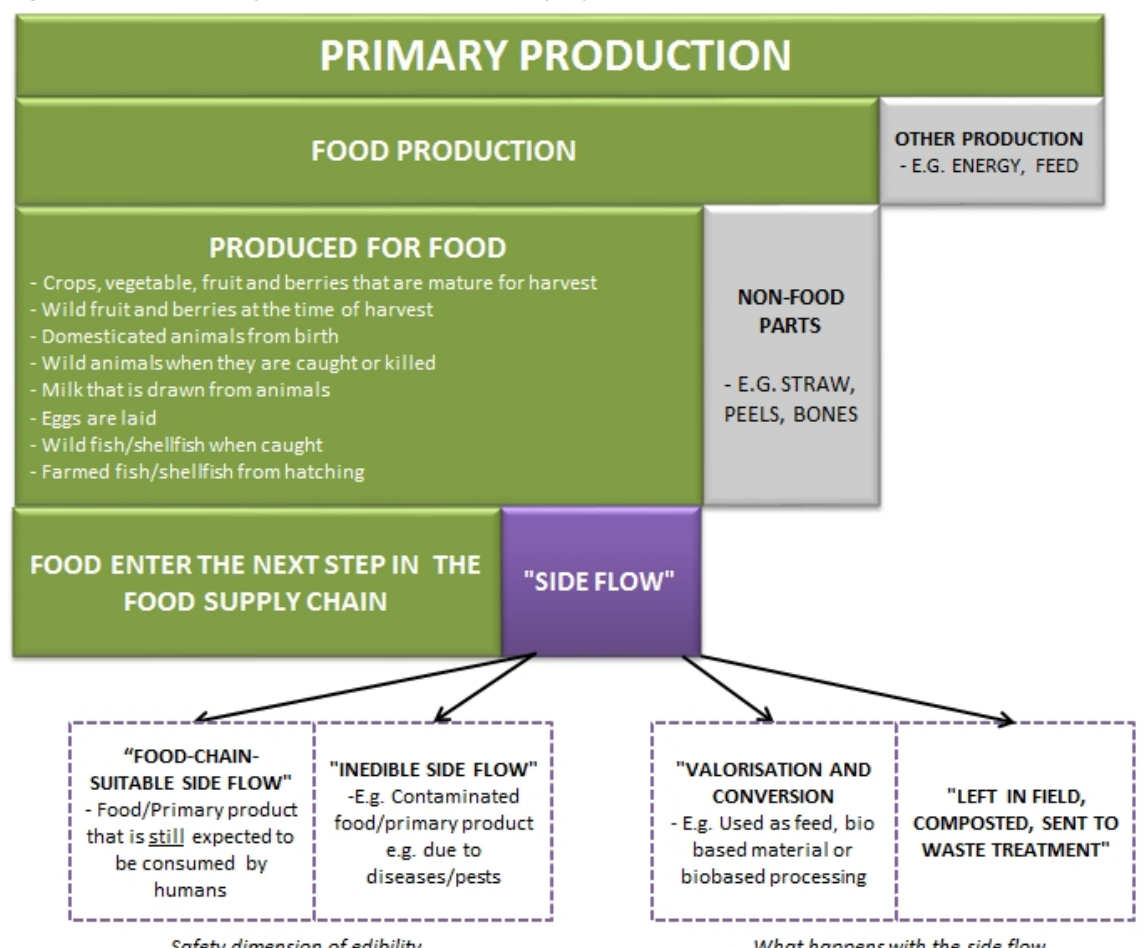

What happens with the side flow

Here "side flow" is considered to be an overall term to define the type of food flow in primary production that was removed from the food supply chain before it entered the next step of the food supply chain (Figure 1).

Side flow is defined as flow that was intended to be eaten by humans and includes only the parts that are expected to be consumed by humans, thus e.g. peels and bones are excluded from side flow. Side flow can be further divided by the uses of the side flow (what happens with the side flow) or by the suitability of the product for human consumption (safety dimension of edibility) when it is removed from the food supply chain (Figure 1). When side flow figures are presented we suggest to further divide side flow into side flow excluding rearing phase (where animal rearing and fish is not included) and side flow of rearing phase (see our reasoning in the next paragraph and in Chapter 3).

In our definition of "side flow" we also define the rearing phase of animals and fish as side flow, whilst it can be argued that the rearing phase is equal to the crop growth phase which we have not included into our system boundaries (Figure 2). This is because: 
- If the death of an animal/fish before they are ready for slaughter is not considered a loss, the counted losses of animal production are a fraction of the losses when animal rearing is also included. From this perspective, excluding the rearing phase, it seems that when trying to reduce losses, the focus will be on crop production whereas meat production will be left out because it does not appear that meat producers have losses. This is not ideal for many reasons. For instance, it is not right to focus on some sectors of primary production while ignoring others. Another reason is that the environmental impact of animal production is much higher than of plant production, therefore more focus, not less, should be put on improving the resource efficiency of animal production.

- "Harvesting" in animal production/fish cultivation is different from crop production since crop production uses a biologically optimal time for harvesting the crop (crop is mature), and the crop cannot be used before it is mature. Meanwhile, animal husbandry and fish farming use an economically optimal time when the animal/fish is slaughtered. Although animals and fish can be slaughtered and the meat used as food at almost any age, the chosen age is often the economic optima. Due to these reasons, we include this "meat quota" for the rearing of animals and fish within our system boundaries.

It should be noted that we only consider "meat side flow" as the amount of meat that was lost up until the point when the animal/fish was dead/put down, therefore we do not include the meat potential (expected amount of meat from animal/fish if the animal/fish had reached the optimal slaughter weight) inside our system boundaries. All in all, because there may be a disagreement on whether the rearing phase should be included or not, we present side flows from the rearing phase separately from the total side flow in Chapter 3.

Because we include animal rearing, it can also be argued that crop growth should be included as well. However, this was not a viable option as we did not have information on unripe crops that were lost during crop cultivation. Additionally, as stated above, unripe crops cannot be used for human food whereas the meat in animal production can potentially be used as human food, even though this might not be economically efficient if there are currently no markets for products from such animals.

As mentioned above we did not include meat potential as part of the side flow. This is the case for all production: we did not include "non-physical" side flows into our scope, such as when the crop yield is lower than expected (e.g. due to suboptimal weather conditions) or when the milk 
production is lower than in an optimal situation (e.g. due to cow illnesses). These suboptimal production circumstances are a problem which require further study to improve the yields in primary production.

The term "intended to be eaten by humans" can be problematic in cases where the product could be used for both human consumption or some other usage, such as animal feed, and where the producer does not have a clear idea before harvest whether it will be used for one purpose or the other. This happens in many cases in cereal production, like for wheat. We propose that only the part of the production volume for human consumption (from the statistics) will be included here. Since the side flow in primary production happens before the production statistics are formed, we calculated total yield as production + side flow, where side flow includes other uses, such as feed use (see further in Subchapter 3.1 and 3.2).

Another issue is the quality of the side flow and its suitability for human consumption. Primary production, in contrast to factory lines, is driven by biological processes which are not standardised. There are several external factors, such as weather and soil conditions that hamper production. Therefore, the output may not meet all the quality demands, whilst, in many cases, the product could still be consumed. One example is small potatoes that are often left in the field due to the buyers' size requirements, but they could be sold as "Parisian potatoes".

Overall, we want to highlight that while side flow includes contaminated produce that is no longer suitable for human consumption, some of the side flow is still edible food that is wasted in primary production, and there are surely some solutions that could reduce this "food-chain-suitable side flow" and bring it back to the food supply chain. Thus, the how the quality of the side flow is considered and addressed, should be taken into consideration, especially when seeking the best practices to reduce side flows.

\subsection{Comparing the definition used in this project to other existing definitions}

There are other guidelines on the quantification of food waste and losses in primary production. Two main guidelines are the FUSIONS Definitional Framework for Food Waste (FUSIONS report) (Östergren et al., 2014) and the Food Loss and Waste Accounting and Reporting Standard (FLW Standard) (WRI 2016). In Table 1 we have compared the main features of the guidelines: terms, definitions, system boundaries and approaches used. 
Table 1: Comparison of guidelines for quantification of food waste/food loss/side flow in the food supply chain

\begin{tabular}{|c|c|c|c|}
\hline & This project & FUSIONS report (Östergren et al., 2014) & FLW Standard (WRI 2016) \\
\hline Terminology & side flow & food waste & food loss and waste \\
\hline Definition(s) & $\begin{array}{l}\text { side flow: } \\
\text { - All production that was in- } \\
\text { tended to be, or reasonably } \\
\text { expected to be, eaten by hu- } \\
\text { man i.e. "food production" } \\
\text { - Removed from the food sup- } \\
\text { ply chain before it enters the } \\
\text { next step of the food supply } \\
\text { chain (often retail or pro- } \\
\text { cessing) } \\
\text { - The part of food production } \\
\text { that is usually consumed, } \\
\text { therefore excluding e.g. peels } \\
\text { and bones }\end{array}$ & $\begin{array}{l}\text { food waste: } \\
\text { - All production that was intended to be, } \\
\text { or reasonably expected to be, eaten by } \\
\text { human } \\
\text { i.e. "food production" } \\
\text { - Removed from the food supply chain to } \\
\text { be recovered or disposed, including the } \\
\text { following destinations: composting, crops } \\
\text { ploughed in/not harvested, anaerobic di- } \\
\text { gestion, bio-energy production, co-genera- } \\
\text { tion, incineration, disposal to sewer, land- } \\
\text { fill or discarded to sea but not including } \\
\text { food or inedible parts of food removed } \\
\text { from the food supply chain to be sent to } \\
\text { animal feed or bio-based material/chemis- } \\
\text { try processing } \\
\text { - Any food and inedible parts of food }\end{array}$ & $\begin{array}{l}\text { food loss and waste (FLW): } \\
\text { - Food that was originally intended for } \\
\text { human consumption } \\
\text { - "Which combination of destinations } \\
\text { may be considered "loss and waste" in a } \\
\text { particular situation will be determined } \\
\text { by factors external to the FLW Protocol" } \\
\text { - The FLW-protocol does not classify } \\
\text { which destinations comprise "loss and } \\
\text { waste". Rather, it gives globally con- } \\
\text { sistent and applicable definitions of } \\
\text { what might be possible destinations for } \\
\text { food and associated inedible parts re- } \\
\text { moved from the food supply chain. } \\
\text { - Food as well as associated inedible } \\
\text { parts removed from the food supply } \\
\text { chain. }\end{array}$ \\
\hline $\begin{array}{l}\text { System } \\
\text { boundaries }\end{array}$ & $\begin{array}{l}\text { - Crops which are mature for } \\
\text { harvest/fruit and berries } \\
\text { which are mature for har- } \\
\text { vest/harvesting of wild crops, } \\
\text { fruit and berries, reared ani- } \\
\text { mals are born/wild animals } \\
\text { which are caught or killed/milk } \\
\text { drawn from animals/eggs laid } \\
\text { by birds/catching of wild } \\
\text { fish/fish from aquacultural is } \\
\text { hatched }\end{array}$ & $\begin{array}{l}\text { - Crops which are mature for har- } \\
\text { vest/fruit and berries which are mature } \\
\text { for harvest/harvesting of wild crops, fruit } \\
\text { and berries/animals who are ready for } \\
\text { slaughter/wild animals which are caught } \\
\text { or killed/milk drawn from animals/eggs } \\
\text { laid by birds/catching of wild fish/fish } \\
\text { from aquacultural is mature in the pond }\end{array}$ & $\begin{array}{l}\text { - Starting from harvest; including har- } \\
\text { vest losses, animals ready for slaughter }\end{array}$ \\
\hline Scope & $\begin{array}{l}\text { - Only primary production } \\
\text { - Nordic }\end{array}$ & $\begin{array}{l}\text { - All food cycle stages } \\
\text { - EU }\end{array}$ & $\begin{array}{l}\text { - All food cycle stages } \\
\text { - Global }\end{array}$ \\
\hline Approach & - Food security approach & $\begin{array}{l}\text { - Waste approach: "how much waste and } \\
\text { what happens with the waste" }\end{array}$ & - Not specified \\
\hline $\begin{array}{l}\text { Target } \\
\text { Group }\end{array}$ & $\begin{array}{l}\text { - Any organization, company, } \\
\text { association, government or } \\
\text { other entity wishing to make } \\
\text { side flow quantification, find- } \\
\text { ing out how the side flow is } \\
\text { treated, understanding side } \\
\text { flow reasons and reducing side } \\
\text { flows. }\end{array}$ & $\begin{array}{l}\text { - EU Member Governments wanting to } \\
\text { make a food waste quantification. The re- } \\
\text { port also gives instructions on secondary } \\
\text { targets such as finding reasons for the } \\
\text { waste and reduction options. }\end{array}$ & $\begin{array}{l}\text { - Any organization, company, associa- } \\
\text { tion, government or other entity wishing } \\
\text { to make a food waste quantification. }\end{array}$ \\
\hline
\end{tabular}

All three guidelines focus on food that was originally intended for human consumption and removed from the food supply chain. The FUSIONS report and FLW Standard both differ from our report in three major aspects (Figure 2):

${ }^{5}$ Removed food going to feed is not considered food waste with this definition. 
- In FUSIONS only destinations that can be classified as waste handling (landfill, incineration, composting) and energy production (e.g. anaerobic degradation and ethanol production) are considered food waste (Figure 2). For example, food that was used as animal feed as an end result is not considered to be food waste. Our study, in contrast, includes all destinations that are not for direct human consumption as "waste", regardless of the uses of the waste. Similarly, the FLW Standard does not classify food losses and waste according to destinations of food losses and waste, however, the difference is that the protocol does not take a stand on the issue. In fact, it states that the decisions to call produce as lost or waste is based on the final destination of produce, and should be determined external to the protocol.

- The FUSIONS report and FLW Standard consider food waste to be "any food and inedible parts of food", whereas our study includes only edible parts of food. Therefore, parts of food that are originally considered "not edible", such as peels and bones, will not be counted as side flow (Figure 2).

- The third aspect where the guidelines differ is the system boundary, more precisely the start of the system (Figure 2). There is an important difference in system boundaries between this project, the FLW Standard and the FUSIONS report. This project includes the rearing phase of domesticated animals and farmed fish inside the system boundaries, but FUSIONS and the FLW Standard exclude it.

Figure 2: System boundaries of this project, FUSIONS report and the FLW Standard

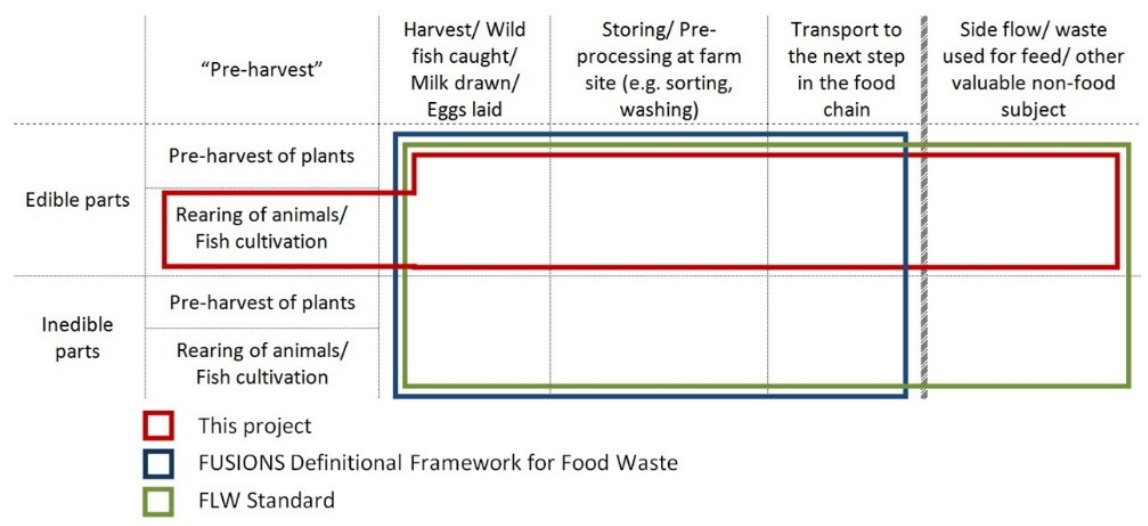





\section{Amount of side flows in Nordic countries}

We calculated the total amount of "side flows" in primary production in Finland, Sweden, Norway and Denmark using the definition and system boundaries of this project. Additionally, we calculated "food waste" in primary production in the four countries using the FUSIONS definition and system boundaries (Östergren et al., 2014). The side flow and food waste estimates are based on the studies in this project and existing literature. The results are represented below (Figure 3), and the data sources and the whole calculation process are represented in this chapter.

Figure 3: Yearly side flow and food waste amounts (1,000 tonnes) in Finland, Sweden, Norway and Denmark. Side flow is counted from edible amount of food production. Edible amount of food production in Finland: 4,162 (1,000 tonnes); Sweden: 5,978; Norway: 3,970; and Denmark: 10,236. Food waste is counted from total food production. Total food production in Finland: 5,037 (1,000 tonnes); Sweden: 8,436; Norway: 5,674; and Denmark: 13,371.

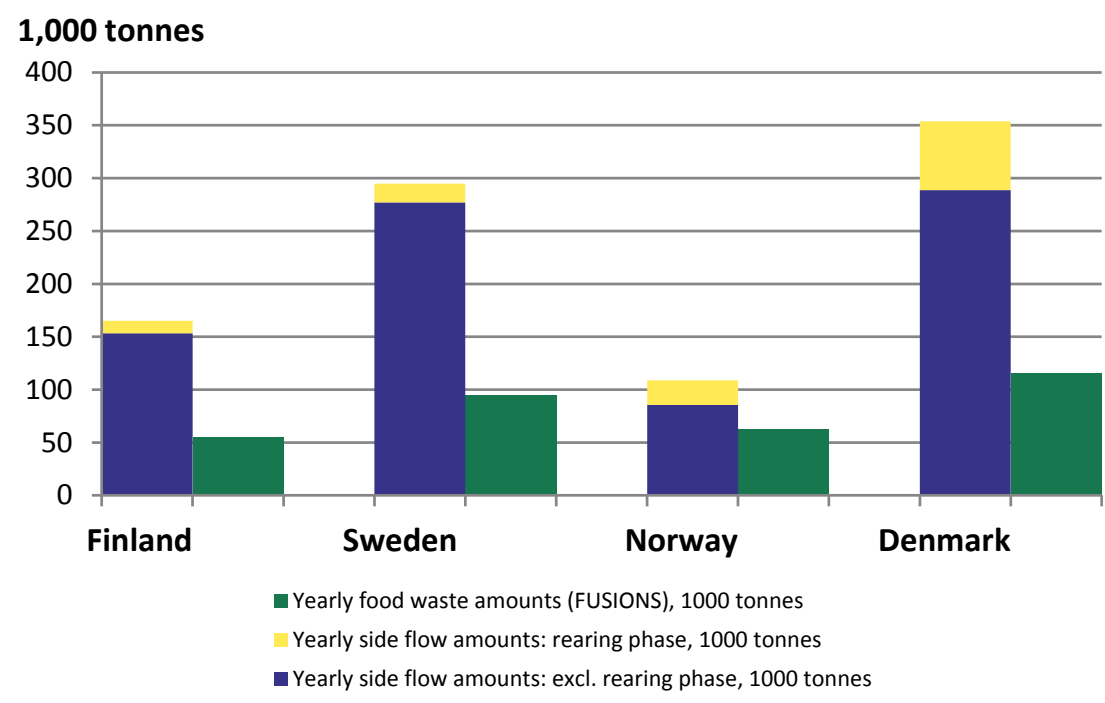

Note: It should be noted that the available data on side flows and food waste from primary production is scarce and there are significant uncertainties in the available data (see Subchapter 3.2). Consequently, we cannot compare countries to one another. Due to several uncertainties and simplifications, one should read the figures and standard estimates within this report as rough estimates. 


\subsection{Food production and conversion factors}

To calculate the amount of side flow and the amount of food waste (using the definition from the FUSIONS report) we needed yearly food production statistics from Finland, Sweden, Norway and Denmark. We used the data from FAOSTAT: crop production and animal production tables, and the food balance sheet for offal, animal fats and fish \& seafood (Table 2) (FAOSTAT 2016). However, one major weakness of the FAOSTAT data is the lack of figures on the original intention of production, meaning how much of the production was originally intended for human consumption. This is especially problematic regarding cereals where cereals are intended for several purposes. To transform the production data to only include food production (including raw materials for drink production such as beer), we made the following alterations:

- Cereals: We used country-specific data from the Cereals balance sheets (Cereals Balance Sheet Finland 2016, Cereals Balance Sheet Sweden 2016, Statistics Denmark 2016, Norwegian Agriculture Agency 2016) to calculate how much of the cereal production is used for human consumption. Therefore, in our approach we only included food use of cereals in the production figures (Table 2).

- Potatoes (starchy roots): We used country-specific statistics to estimate the amount of potatoes that is used for human consumption (excluding starch production (to produce paper and other non-food items), feed and seed) (Balance Sheet for Food Commodities Finland 2016, Breen \& Vengnes 2016, Jordbruksverket 2015, Statistics Denmark 2016). Hence, we only included food uses of potatoes in the production figures (Table 2).

- Oil crops: Gustavsson et al. (2013) found that a large part of oil crops is used for feed, seed, bio-energy and soap production. Only around $20 \%$ of the domestic supply of oil crops is used for human consumption in Europe on average, so we excluded $80 \%$ of oil crops from the production figures (Table 2).

- Fish: We estimated that in Norway $70 \%$ of wild and $100 \%$ of cultivated fish is for human consumption (Norwegian Statistics Agency 2016); in Sweden 53\% of wild - and 100\% cultivated fish is for human consumption (SCB 2016); in Finland and Denmark we used a rough average: $62 \%$ of wild - and $100 \%$ of cultivated fish is for human consumption and thus we excluded $30-47 \%$ of wild fish from the production figures (Table 2). 
Table 2: Food production (1,000 tonnes) in Finland, Sweden, Norway and Denmark, Yearly average from years 2010-13 (FAOSTAT crop production - and animal production tables from years 2010-13, and FAOSTAT food balance sheet for offal, animal fats and fish \& seafood from 2010-11

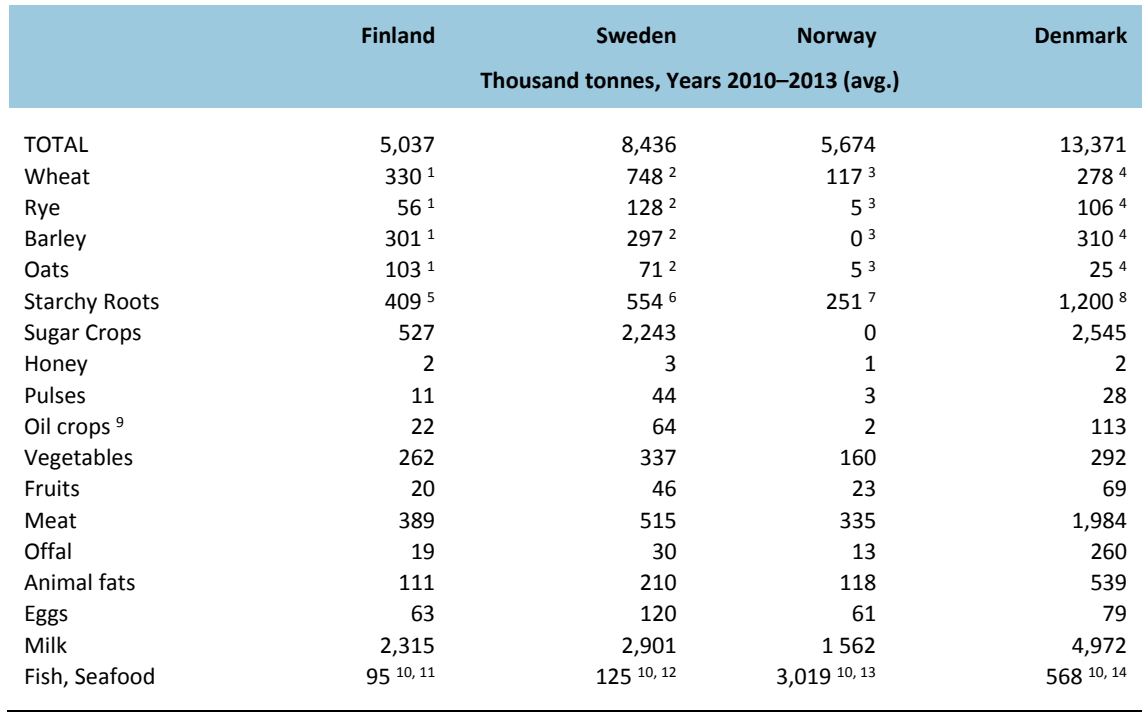

Note: ${ }^{1}$ Cereals used as food (38\% of wheat, $95 \%$ of rye, $19 \%$ of barley, $10 \%$ of oats) (Cereals Balance Sheet Finland 2016).

${ }^{2}$ Cereals used as food (35\% of wheat, $95 \%$ of rye, $19 \%$ of barley, $10 \%$ of oats) (Cereals Balance Sheet Sweden 2016).

${ }^{3}$ Cereals used as food (43\% of wheat, $32 \%$ of rye, $0 \%$ of barley, $2 \%$ of oats) (Norwegian Agriculture Agency 2016).

${ }^{4}$ Cereals used as food ( $6 \%$ of wheat, $29 \%$ of rye, $9 \%$ of barley, $9 \%$ of oats) (Statistics Denmark 2016).

${ }^{5}$ Potatoes used as food (67\%) (Balance Sheet for Food Commodities Finland 2016).

${ }^{6}$ Potatoes used as food (67\%) (Marknadsöversikt potatis till mat och stärkelseproduktion 2015).

${ }^{7}$ Potatoes used as food (80\%) (Breen \& Vengnes 2016).

${ }^{8}$ Potatoes used as food (77\%) (Statistics Denmark 2016).

${ }^{9}$ Assumed that $20 \%$ of the oil crop domestic supply is for human consumption (Gustavsson et al., 2013).

${ }^{10}$ Assumed that in Norway $70 \%$ of wild and $100 \%$ cultivated fish is for human consumption (Norwegian Statistics Agency 2016); in Sweden 53\% of wild - and 100\% cultivated fish is for human consumption (SCB 2016); in Finland and Denmark we used a rough average: $62 \%$ of wild - and $100 \%$ of cultivated fish is for human consumption.

${ }^{11}$ Shares of wild fish and fish cultivation: 91\% and 9\% (Finnish Fisheries Statistics 2012 \& 2014).

${ }^{12}$ Share of wild fish and fish cultivation: $94 \%$ and $6 \%$ (SCB 2016).

${ }^{13}$ Share of wild fish and fish cultivation: $63 \%$ and $37 \%$ (Norwegian Statistics Agency 2016).

${ }^{14}$ Share of wild fish and fish cultivation: $96 \%$ and $4 \%$ (Statistics Denmark 2016).

It is important to note that while we only included part of the production that is intended for human consumption (corrections to the production volumes of cereals, starchy roots (thus potatoes), oil crops, and fish), and excluded the part of production that is used for feed from the production figures (Table 2), we did not exclude feed use from the side flow percentages 
(Table 4). This is because we consider the feed use of food production (i.e. production that was intended for human consumption) as side flow. Consequently, the side flow percentages that have been used can be somewhat distorted. All in all, the chosen methods have their weaknesses and should be considered as the first attempts to estimate side flows in the food chain.

We used certain conversion factors to convert the food production figures to exclude inedible parts of food and to convert production quantities into the amount of the production that can be consumed (to match the system boundaries of this project). The conversion factors and explanations are presented in Table 3. To calculate food waste using the FUSIONS report definition we used the total production figures (Table 2) without conversion factors. This was because in the FUSIONS report any food and inedible parts of food are included within the system boundaries.

\begin{tabular}{|c|c|c|}
\hline & Conversion factor & Explanation \\
\hline Wheat, Rye, Barley, Oats & 0.78 & $\begin{array}{l}\text { To convert cereals to milled equivalents } \\
\text { (Gustavsson et al., 2013) }\end{array}$ \\
\hline Starchy Roots & 0.82 & $\begin{array}{l}\text { One conversion factor for potato was used as a mean of in- } \\
\text { dustrial peeling and peeling by hand } \\
\text { (Gustavsson et al., 2013) }\end{array}$ \\
\hline Sugar Crops & 0.20 & $\begin{array}{l}\text { For sugar crops, i.e. sugar beet, we only included } 20 \% \text { of } \\
\text { production, since roughly } 20 \% \text { of the beet is sugar }\end{array}$ \\
\hline Vegetables & 0.77 & $\begin{array}{l}\text { One conversion factor for vegetables was used as a mean of } \\
\text { industrial peeling and peeling by hand } \\
\text { (Gustavsson et al., 2013) }\end{array}$ \\
\hline Fruits & 0.77 & $\begin{array}{l}\text { One conversion factor for fruits was used as a mean of in- } \\
\text { dustrial peeling and peeling by hand } \\
\text { (Gustavsson et al., 2013) }\end{array}$ \\
\hline Meat: bovine, pig, poultry & $0.70,0.80,0.60$ & $\begin{array}{l}\text { To convert carcass to boneless meat. } \\
\text { (House to Homestead 2011, Raines 2015) }\end{array}$ \\
\hline Fish, Seafood & 0.50 & $\begin{array}{l}\text { To convert round fish to fish filet } \\
\text { (Gustavsson et al., 2013) }\end{array}$ \\
\hline
\end{tabular}

\subsection{Side flow and food waste}

To estimate side flows and food waste (using the FUSIONS report definition for food waste) in primary production, we used the results of the studied products (i.e. wheat, rye, carrot, onion, field pea, green pea, rainbow trout), (see more in Chapter 4), and we carried out a literature review. 
We further divided 14 food categories into 42 subcategories (Table 4). For each subcategory we used the best available estimate to calculate side flow and food waste (according to the FUSIONS report) (see Table 4). We used a standard side flow estimate excluding the rearing phase (\%), side flow estimate of the rearing phase (\%), and a standard food waste estimate (\%) per food item across all countries (Finland, Sweden, Norway and Denmark). Generally, these standard estimates are highly uncertain and it was not possible to make country-specific estimates for side flow and/or food waste.

We have not presented the exact uncertainties (as values) of the side flow and food waste since some of the references do not present uncertainties. Additionally, the uncertainty of 1) using one standard estimate that represents all countries and 2) taking one product estimate to represent other products (e.g. side flow estimate of rye to represent oat and barley) creates so much uncertainty that it is impossible to say how much the total uncertainty actually is (including the uncertainty of side flow studies). Moreover, many uncertainty indicators, such as standard deviations, do not give us a sufficient picture of the uncertainty if the sample is not a representative sample, which in agricultural samples is unfortunately often the case since the sample sizes need to be large in order them to be representative (see Appendix 1). In total, we state that the uncertainties involved with our figures are large and one should not consider these figures to be accurate, rather as indicative figures based on the current knowledge.

Moreover, the FUSIONS definition requires information on what happens to the waste in order to calculate food waste. This information is not always available, therefore we had to report product categories where the side flow or food waste value is "missing". However, it should be noted that among side flow and food waste the missing categories comprise of a small share of the production volume. For side flow the missing categories are comprised of less than $2 \%$, and for food waste the missing categories are comprise of less than $4 \%$. All in all, the impact of "missing" categories to the final side flow and food waste estimates is very small.

The references and reasoning behind the side flow and food waste estimates (Table 4) are presented in Subchapters: 3.2.1-3.2.6. 
Table 4: Standard estimates of "Side flow" (defined in this project) - and "food waste" (defined in the FUSIONS report

\begin{tabular}{|c|c|c|}
\hline Product categories & $\begin{array}{r}\text { Side flow percentage } \\
\text { (+ rearing phase percentage) }\end{array}$ & Food waste percentage \\
\hline \multicolumn{3}{|l|}{ Cereals } \\
\hline Wheat & $14.0 \%^{\mathrm{a}}$ & $1.0 \%^{\mathrm{a}}$ \\
\hline Rye & $4.0 \%{ }^{\mathrm{a}}$ & $1.5 \%^{\mathrm{a}}$ \\
\hline Barley & $4.0 \%^{\mathrm{a}}$ & $1.5 \%^{\mathrm{a}}$ \\
\hline Oats & $4.0 \%^{a}$ & $1.5 \%{ }^{\mathrm{a}}$ \\
\hline \multicolumn{3}{|l|}{ Starchy Roots } \\
\hline Potatoes & $10.0 \%^{\mathrm{b}}$ & $2.5 \%^{\mathrm{b}}$ \\
\hline \multicolumn{3}{|l|}{ Sugar Crops } \\
\hline Sugar beet & $5.0 \%^{\mathrm{b}}$ & Missing \\
\hline \multicolumn{3}{|l|}{ Honey } \\
\hline Honey & Missing & Missing \\
\hline \multicolumn{3}{|l|}{ Pulses } \\
\hline Beans & $17.0 \%^{\mathrm{c}}$ & $4.0 \%^{c}$ \\
\hline Peas, field & $17.0 \%^{\mathrm{c}}$ & $4.0 \%^{c}$ \\
\hline Pulses, Other and products & $17.0 \%^{c}$ & $4.0 \%^{c}$ \\
\hline \multicolumn{3}{|l|}{ Oil crops } \\
\hline Rape and Mustard seed & $3.0 \%{ }^{a}$ & Missing \\
\hline Oil crops, Other & $3.0 \%{ }^{a}$ & Missing \\
\hline \multicolumn{3}{|l|}{ Vegetables } \\
\hline Tomatoes & $1.0 \%{ }^{\mathrm{c}}$ & Missing \\
\hline Onions, shallots, green & $15.0 \%^{\mathrm{c}}$ & $15.0 \%^{c}$ \\
\hline Cabbages and brassicas & $15.0 \%^{c}$ & Missing \\
\hline Cauliflowers and broccoli & $13.0 \%^{\mathrm{c}}$ & Missing \\
\hline Lettuce and chicory & $17.0 \%^{\mathrm{c}}$ & $17.0 \%^{c}$ \\
\hline Cucumbers and gherkins & $1.0 \%^{\mathrm{c}}$ & Missing \\
\hline Peas, green & $19.0 \%^{c}$ & $17.0 \%^{c}$ \\
\hline Carrots and turnips & $26.0 \%^{c}$ & $14.0 \%^{c}$ \\
\hline Mushrooms and truffles & $1.0 \%$ c & Missing \\
\hline Vegetables, Other & $15.0 \%^{\mathrm{c}}$ & Missing \\
\hline \multicolumn{3}{|l|}{ Fruits } \\
\hline Apples & $10.0 \%^{\mathrm{d}}$ & Missing \\
\hline Pears & $10.0 \%^{\mathrm{d}}$ & Missing \\
\hline Strawberry & $14.0 \%^{\mathrm{d}}$ & $14.0 \%^{d}$ \\
\hline Currants & $14.0 \%^{\mathrm{d}}$ & $14.0 \%^{d}$ \\
\hline Fruits, Other & $10.0 \%^{\mathrm{d}}$ & Missing \\
\hline \multicolumn{3}{|l|}{ Meat } \\
\hline Beef & $0.7 \%(+8.3 \%)^{\mathrm{e}}$ & $0.7 \%^{\mathrm{e}}$ \\
\hline Mutton \& Goat Meat & Missinge & Missinge \\
\hline Pork & $0.2 \%(+2.8 \%)^{e}$ & $0.2 \%$ \\
\hline Poultry & $1.7 \%(+1.3 \%)^{\mathrm{e}}$ & $1.7 \% \mathrm{e}^{\mathrm{s}}$ \\
\hline Meat, Other & $0.7 \%(+3.3 \%)^{\mathrm{e}}$ & $0.7 \%{ }^{\mathrm{e}}$ \\
\hline \multicolumn{3}{|l|}{ Offal } \\
\hline Offal & $0.7 \%(+3.3 \%)^{\mathrm{e}}$ & $0.7 \%{ }^{\mathrm{e}}$ \\
\hline \multicolumn{3}{|l|}{ Animal fats } \\
\hline Butter, Ghee & $0.3 \%^{f}$ & $0.3 \%^{f}$ \\
\hline Cream & $0.3 \%^{f}$ & $0.3 \%^{f}$ \\
\hline Fats, Animals, Raw & $0.7 \%(+3.3 \%)^{e}$ & $0.7 \%{ }^{\mathrm{e}}$ \\
\hline Fish oil & Missingg & Missingg \\
\hline
\end{tabular}




\begin{tabular}{|c|c|c|}
\hline Product categories & $\begin{array}{r}\text { Side flow percentage (+ rearing phase per- } \\
\text { centage) }\end{array}$ & Food waste percentage \\
\hline \multicolumn{3}{|l|}{ Eggs } \\
\hline Eggs & $3.6 \%^{f}$ & $3.6 \%^{f}$ \\
\hline \multicolumn{3}{|l|}{ Milk } \\
\hline Milk & $0.3 \%^{f}$ & $0.3 \%^{f}$ \\
\hline \multicolumn{3}{|l|}{ Fish, Seafood } \\
\hline Farmed Fish & $0.7 \%(+1.9 \%)^{\mathrm{g}}$ & $0.7 \%^{\mathrm{g}}$ \\
\hline Fish, caught & $\begin{array}{r}0.7 \% \text { (+ Missing fish discards during fish- } \\
\text { ing) }{ }^{\mathrm{g}}\end{array}$ & $0.7 \% \mathrm{~g}$ \\
\hline Seafood & Missingg & Missingg \\
\hline
\end{tabular}

Note: $\quad{ }^{a}$ Further explanations in Subchapter: 3.2.1.

${ }^{\mathrm{b}}$ Further explanations in Subchapter: 3.2.2.

${ }^{\mathrm{c}}$ Further explanations in Subchapter: 3.2.3.

${ }^{d}$ Further explanations in Subchapter: 3.2.4.

e Further explanations in Subchapter: 3.2.5.

${ }^{f}$ Further explanations in Subchapter: 3.2.6.

${ }^{\mathrm{g}}$ Further explanations in Subchapter: 3.2.7.

The side flow and food waste amounts for all four countries are represented in Table 5. The production statistics (Table 2) do not include side flow or food waste from primary production, therefore we calculated side flow and food waste amounts in Table 5 using the following formulas:

- $\quad$ Total yield $=p * \frac{1}{1-s f}$

- $\quad$ Side flow $=p * \frac{1}{1-s f} * s f * c f$

- Food waste $=p * \frac{1}{1-s f} * \mathrm{fw}$

Where

- $\mathrm{p}=$ production amount (Table 2 )

- $\mathrm{cf}=$ conversion factor (Table 3 )

- $\mathrm{sf}=$ side flow $\%$ (Table 4$)$

- $\mathrm{fw}=$ food waste $\%$ (Table 4) 


\begin{tabular}{|c|c|c|c|c|c|c|c|c|}
\hline & \multicolumn{2}{|c|}{ Finland } & \multicolumn{2}{|c|}{ Sweden } & \multicolumn{2}{|c|}{ Norway } & \multicolumn{2}{|c|}{ Denmark } \\
\hline & \multicolumn{8}{|c|}{ Thousand tonnes, 2010-2013 (avg.) } \\
\hline & $\begin{array}{r}\text { Side flow } \\
\text { +rearing } \\
\text { phase }\end{array}$ & $\begin{array}{r}\text { Food } \\
\text { waste }\end{array}$ & $\begin{array}{r}\text { Side flow } \\
\text { +rearing } \\
\text { phase }\end{array}$ & $\begin{array}{r}\text { Food } \\
\text { waste }\end{array}$ & $\begin{array}{r}\text { Side flow } \\
\text { +rearing } \\
\text { phase }\end{array}$ & $\begin{array}{r}\text { Food } \\
\text { waste }\end{array}$ & $\begin{array}{r}\text { Side flow } \\
\text { +rearing } \\
\text { phase }\end{array}$ & $\begin{array}{r}\text { Food } \\
\text { waste }\end{array}$ \\
\hline TOTAL & $153+13$ & 60 & $277+18$ & 98 & $85+23$ & 61 & $288+65$ & 117 \\
\hline Wheat & 42 & 4 & 95 & 9 & 15 & 1 & 35 & 3 \\
\hline Rye & 2 & 1 & 4 & 2 & 0 & 0 & 10 & 2 \\
\hline Barley & 10 & 5 & 10 & 5 & 0 & 0 & 11 & 5 \\
\hline Oats & 4 & 2 & 2 & 1 & 0 & 0 & 1 & 0 \\
\hline Starchy Roots & 37 & 11 & 50 & 15 & 23 & 7 & 109 & 33 \\
\hline Sugar Crops & 6 & 0 & 24 & 0 & 0 & 0 & 27 & 0 \\
\hline Pulses & 2 & 1 & 9 & 2 & 1 & 0 & 6 & 1 \\
\hline Oil crops & 1 & 0 & 2 & 0 & 0 & 0 & 3 & 0 \\
\hline Vegetables & 35 & 21 & 57 & 42 & 25 & 16 & 49 & 33 \\
\hline Fruits & 3 & 2 & 5 & 2 & 3 & 1 & 7 & 3 \\
\hline Meat & $2+11$ & 3 & $2+15$ & 4 & $2+9$ & 2 & $5+46$ & 8 \\
\hline Offal & $0+1$ & 0 & $0+1$ & 0 & $0+0$ & 0 & $2+9$ & 2 \\
\hline Animal fats & $0+1$ & 0 & $1+2$ & 1 & $0+1$ & 0 & $2+10$ & 2 \\
\hline Eggs & 2 & 2 & 4 & 4 & 2 & 2 & 3 & 3 \\
\hline Milk & 7 & 7 & 9 & 9 & 5 & 5 & 16 & 15 \\
\hline Fish, Seafood & $0+0$ & 0 & $0+0$ & 2 & $10+13$ & 26 & $2+0$ & 6 \\
\hline
\end{tabular}

\subsubsection{Cereals, oil crops}

\section{Wheat}

Side flow: $14 \%$, Food waste: $1 \%$ According to a Finnish questionnaire answered by 700 wheat farmers (where wheat was produced for human consumption) the side flow is $16 \%$ (wheat left in field and sorted out in sorting), and around $1 \%$ is not used as valuable output since most of the side flow is used as animal feed (Hartikainen et al., 2014). A Swedish questionnaire answered by 306 farmers reported 23\% side flow, a Danish questionnaire answered by 125 farmers reported 5\% side flow, and a Norwegian questionnaire answered by 614 farmers reported $6.6 \%$ side flow (results of this project). Due to the high variability of side flow estimates, we used a rough standard estimate: $14 \%$ and assumed $1 \%$ food waste. Since wheat production is one of the biggest production categories and wheat side flows are relatively high - the chosen standard estimate has significant impact to the side flow amounts (Table 5). Therefore, in order to demonstrate the uncertainty of the chosen estimate, we have calculated the total side flow amounts for the four countries using different standard estimates for wheat in Subchapter 3.3 (Figure 4). 
Rye

Side flow: 4\%, Food waste: $1.5 \%$ According to a Finnish questionnaire answered by 206 rye farmers the side flow is on average 4\% (rye left in field and sorted out in sorting) and around $1.5 \%$ is not used as valuable output (results of this project).

\section{Barley}

Side flow: 4\%, Food waste: $1.5 \%$ Estimated to be same as "Rye".

\section{Oats}

Side flow: 4\%, Food waste: $1.5 \%$ Estimated to be same as "Rye".

\section{Oil crops}

Side flow: 3\%, Food waste: missing. The Swedish producer organisations calculated production losses in reporting to the EAA as 3\% Jordbruksverket, 2006). Similarly, yield loss in the cultivation of oil seeds in the UK is estimated between $2-5 \%$ in optimum conditions $(20-25 \%$ at the highest) (Hobson \& Bruce 2002).

\subsubsection{Starchy roots, sugar crops}

\section{Potatoes}

Side flow: 10\%, Food waste: $2.5 \%$. According to data on potatoes lost in harvest and potatoes removed at sorting in Swedish cultivation from years 1987-1998, the potato side flow is 9.5\% (Ländell \& Wahlstedt 2012). According to a Finnish questionnaire answered by 72 potato farmers the side flow is $16 \%$ (potato left in field and sorted out in sorting) of which $25 \%$ is not used as valuable output (Hartikainen et al., 2014). We used a more conservative standard estimate (rounding 9.5\% to $10 \%$ ) for potato but estimated that $25 \%$ of the side flow ( $2.5 \%$ of total production) is not used as valuable output. Therefore it is considered food waste according to the FUSIONS definition.

\section{Sugar beet}

Side flow: 5\%, Food waste: missing. According to a Swedish expert (personal communication in November 2015 with Ola Christiansson at Nordic Sugar for this project: represents results of Sweden Nordic Beat Research) $3.5 \%$ of sugar beets are lost at harvest. Additionally, according to the expert, half of the production also suffers from an additional 3\% loss due to layering. Therefore, we estimate sugar beet side flow at roughly $5 \%$. 


\subsubsection{Vegetables, pulses}

\section{Tomatoes}

Side flow: 1\%, Food waste: missing. According to interviews with Swedish farmers and producer organisations the loss of ordinary round tomatoes was estimated at 0-2\% in primary production (Andersson 2013).

\section{Onions, green shallots}

Side flow: 15\%, Food waste: 15\%. Onion losses in Swedish production were estimated at 16-20\% (Jordbruksverket 2009), and in another study a $17 \%$ loss was calculated from amount harvested to amount stored and sorted on the farm (Davis et al., 2011). Meanwhile a Swedish study, based on farmers' own sorting statistics during five years, $11-16 \%$ of the yellow onions and $17-30 \%$ of the red onions were discarded at delivery (Olsson et al., 2011). Results from a Norwegian case study, based on interviews of 6 onion producers and 2 persons from packing plants, show storage losses ranging from $6.5 \%$ to $20 \%$ (Franke et al., 2013). Furthermore, according to a Finnish questionnaire answered by 27 onion farmers the side flow is approximately $11 \%$ (onions left in field and sorted out during sorting), and none of the side flow is turned into valuable output (results of this project). A Swedish questionnaire answered by 45 farmers reported 17-33\% side flow, a Danish questionnaire answered by 17 farmers reported 21\% side flow, and a Norwegian questionnaire answered by 17 farmers reported $8 \%$ side flow (results of this project). We used a rough standard estimate based on these studies (15\%), and further estimated that none of the onion side flow is used as valuable output, meaning it is considered food waste according to the FUSIONS -definition.

\section{Cabbages and brassicas}

Side flow: 10\%, Food waste: missing. According to a Swedish study the losses in cabbage production are $15 \%$ in conventional production (Jordbruksverket, 2009), and in another study there was an 8\% loss calculated from the total amount harvested on the farm (Davis et al., 2011). We used a rough standard estimate based on these studies for a total of $10 \%$.

\section{Cauliflowers and broccoli}

Side flow: 13\%, Food waste: missing. We were not able to find Nordic studies on losses in cauliflower and broccoli production, so we used a UK study instead. The UK has mapped a 13\% loss of cauliflower at harvest and sorting. Data were collected through interviews and questionnaires in England, Scotland and Wales (Terry et al., 2011). 


\section{Lettuce and chicory}

Side flow: 17\%, Food waste: 17\%. According to a Swedish study (Strid et al., 2014a) $5 \%$ of the lettuce heads are rejected at harvest and $15 \%$ of the cultivated lettuce fields will never be harvested. According to a Finnish questionnaire answered by 7 lettuce farmers the side flow is $17 \%$ (lettuce left in field and sorted out during sorting) which is not used as valuable output (Hartikainen et al., 2014). We used a rough standard estimate based on the studies (17\%), and further estimated that none of the lettuce side flow is used as valuable output, meaning it is considered food waste according to the FUSIONS definition.

\section{Cucumbers and gherkins}

Side flow: $1 \%$, Food waste: missing. We estimate it to be same as the category "Tomato" as there is a lack of data. This might be a slight underestimation because, according to a Swedish expert, cucumber in greenhouses have a slightly higher side flow than tomatoes since more chemicals are used in cucumber production and there are probably more quality reasons for sorting out cucumbers e.g. sorting out hooked cucumbers. However, the expert could not say exactly how much greater the side flow is (Personal communication in November 2015 with Inger Christensen at Grön Kompetens, result of this project).

\section{Peas, green}

Side flow: $18 \%$, Food waste: $17 \%$. According to a Finnish questionnaire answered by 37 green pea farmers the side flow is $17 \%$ (green peas left in field and sorted out in sorting) of which around $16 \%$ is not used as valuable output (mostly left in the field), therefore it is considered food waste according to the FUSIONS definition (results of this project). According to a Swedish questionnaire answered by two commercial pea buyers (there are three big commercial buyers in Sweden that represent around 500 contracted farmers and roughly $90 \%$ of the area), around $4 \%$ of green pea is lost at harvest, including not harvested fields, and around $17 \%$ are lost in cleaning, sorting, blanching and freezing. Therefore the overall side flow is around $21 \%$ (results of this project). We used a rough standard estimate of $19 \%$ based on these studies, and further estimated that $17 \%$ of the green pea side flow is not used as valuable output, and so is considered food waste according to the FUSIONS definition.

\section{Carrots and turnips}

Side flow: 26\%, Food waste: 14\%. Carrot losses in Swedish production were estimated at 25-30\% (Jordbruksverket 2009), and in another study $25-28 \%$ loss was calculated from amount harvested to amount 
stored and sorted on the farm (Davis et al., 2011). Results from a Norwegian case study, based on interviews of seven carrot producers and one person from a packing plant, show field waste is $1.6 \%$ and storage loss is $25 \%$ (Franke et al., 2013). Furthermore, according to a Finnish questionnaire answered by 27 carrot farmers, the side flow is on average $26 \%$ (onions left in field and sorted out in sorting), and $14 \%$ of the side flow is not used as valuable output (results of this project). A Swedish questionnaire answered by 70 farmers reported $13-31 \%$ side flow (the longer the storage time the higher the side flow estimate), and a Norwegian questionnaire answered by 52 farmers reported $18 \%$ side flow (results of this project). We used a rough standard estimate of $26 \%$ based on the studies, and further estimated that $14 \%$ of the carrot side flow is not used as valuable output and so is considered food waste according to the FUSIONS definition.

\section{Mushrooms and truffles}

Side flow: 1\%, Food waste: missing. Estimated to be same as the category "Tomato" since cultivated mushrooms are also produced in greenhouses. Additionally, wild mushrooms are only included at the point of harvest, where mushrooms left in the forest are not counted, and therefore we expect the side flow of wild mushrooms to be rather small.

\section{Vegetables, Other}

Side flow: 15\%, Food waste: missing. We used a rough standard estimate $(15 \%)$ based on other vegetable studies on production losses.

\section{Beans}

Side flow: 17\%, Food waste: $4 \%$. Estimated to be same as "Field pea".

\section{Peas, field}

Side flow: 17\%, Food waste: 4\%. A Swedish questionnaire answered by 16 farmers reported $16.5 \%$ side flow, and a Danish questionnaire answered by 64 farmers reported $18 \%$ side flow (results of this project). According to a Finnish questionnaire answered by 37 green pea farmers the side flow is $17 \%$ (field pea left in field and sorted out in sorting) of which around $4 \% 6$ is not used as valuable output, therefore it is considered food waste according to the FUSIONS definition (results of this project).

\section{Pulses, Other and products}

Side flow: $17 \%$, Food waste: $4 \%$. Estimated to be same as "Field pea".

${ }^{6}$ Food waste is lower than for green pea since most of the side flow is used as animal feed. 


\subsubsection{Fruits}

\section{Apples}

Side flow: 10\%, Food waste: missing. According to a Swedish study at apple cultivation $5-10 \%$ of apples fall to the ground and cannot be used due to the risk of mycotoxin (Mattsson 2014). The UK has mapped 16-62\% loss of apples at harvest, sorting, storage and packing. Data were collected through interviews and questionnaires in England, Scotland and Wales (Terry et al., 2011). We used a 10\% estimate for apple.

\section{Pears}

Side flow: 10\%, Food waste: missing. Estimated to be same as "Apple".

\section{Strawberry}

Side flow: $14 \%$, Food waste: $14 \%$. According to a Swedish study on strawberry cultivation $10-25 \%$ of the strawberries are lost during harvest and sorting (Franke et al., 2013). According to a Finnish questionnaire answered by 68 strawberry farmers the side flow is 14\% (strawberries left in the field and sorted out in sorting) and none of the side flow is further used as valuable output (Hartikainen et al.,. 2014). We used 14\% as a rough standard estimate of strawberries lost in production and estimated that none of the side flow is used as valuable output, and so considered food waste according to the FUSIONS definition.

\section{Currants}

Side flow: 14\%, Food waste: 14\%. Estimated to be same as "Strawberry".

\section{Fruits, Other}

Side flow: 10\%, Food waste: missing. Estimated to be same as "Apple".

\subsubsection{Meat, offal, animal fats}

\section{Bovine Meat}

Side flow: $0.7 \%+8.3 \%$ (rearing phase), Food waste: $0.7 \%$. According to a Swedish study, where they used existing statistics, $9 \%$ of the cattle live weight (biomass) is lost before slaughter. This includes losses in the form of stillborn calves, calf mortality, deaths among older animals and rejects in inspections before and after slaughter (Strid et al., 2014b). Similarly, according to a Finnish study based on statistics on rejected cattle (by law you must report the deaths/putt down of cattle) the side flow was estimated as 9.5\%. Additionally, a recent Danish study (Raundal et al., 2015) 
showed a $9 \%$ side flow. We used $9 \%$ as a rough standard estimate of bovine meat lost in production (including transportation and rejections at the slaughter house). According to the FUSIONS definition only animals ready for slaughter are included within their system boundaries. Gustavsson et al. (2013) estimated that $0.1 \%$ of cattle are lost at transport to slaughter and $0.6 \%$ are rejected at slaughter, therefore approximately $0.7 \%$ are considered food waste according to the FUSIONS definition. Since $0.7 \%$ represents losses after the rearing phase we calculated that of the $9 \%$ side flow, $8.3 \%$ represent the rearing phase $(9.0-0.7=8.3)$.

\section{Mutton \& Goat Meat}

Side flow: missing, Food waste: missing.

\section{Pig meat}

Side flow: $0.2 \%+2.8 \%$ (rearing phase), Food waste: $0.2 \%$. According to a recent Danish study (Enemark, 2015), it was estimated that 3.7\% of the pig live weight is lost before slaughter. In Finland, this was estimated using AgroSoft WebStat data that showed pig side flow was 2\%, whereas based on statistics on rejected pigs (required by law) the Finnish pig side flow was estimated at 3.5\% (Hartikainen et al., 2014). We used the $3 \%$ as a rough standard estimate of pig meat lost in the Nordic pig production. According to the FUSIONS definition only animals ready for slaughter are included within their system boundaries. Gustavsson et al. (2013) estimated that $0.1 \%$ of pigs are lost at transport to slaughter and $0.1 \%$ are rejected at slaughter, therefore around $0.2 \%$ are considered food waste according to the FUSIONS definition. Since $0.2 \%$ represents losses after the rearing phase we calculated that, of the $3 \%$ side flow, $2.8 \%$ represents the rearing phase $(3.0-0.2=2.8)$.

\section{Poultry Meat}

Side flow: $1.7 \%+1.3 \%$ (rearing phase), Food waste: $1.7 \%$. According to a Swedish study the mortality in chicken breeding is 3.5\% (Kronfågel 2008 in Cederberg et al., 2009), and another study estimates it is around 3\% (Maria Donis, President of the Swedish Bird personal communication, Franke et al., 2013). In a Danish study mortality was estimated between 3.1-3.5\% (Det danske fjærkrærås 2013). We used a more conservative standard estimate of $3 \%$ as the estimate of poultry meat lost in production (side flow). According to the FUSIONS definition only animals ready for slaughter are included within their system boundaries. Livsmedelsverkets statistics show that $0.2 \%$ of all chickens arriving at the slaughterhouse are dead (Gale Gunilla, 2012, personal communica- 
tion in Franke et al., 2013). Discarded Swedish chickens at the slaughterhouse are around 1-2\% (based on statistics between 2005 and 2011: Agriculture's statistical database from Jordbruksverkets statistic database 2012). We used $1.7 \%$ as a rough estimate of "chicken" food waste according to the FUSIONS definition. Since $1.7 \%$ represents losses after the rearing phase we calculated that of the $3 \%$ side flow approximately $1.3 \%$ represents the rearing phase $(3.0-1.7=1.3)$. It should be noted that side flow and food waste figures do not include poultry meat losses from egg production which includes laying hens that are taken out of production and day old male chicks that are killed at the hatchery when sex is determined. This presents a significant figure, since, according to a Swedish study, up to $33 \%$ of laying hens are either disposed of or used as mink feed, mainly because the current transportation regulations do not allow the farmers from the Northern part of Sweden to send their hens to slaughter (Jordbruksverket 2016). Around 5.6 million laying hens are replaced each year in Sweden. Additionally, nearly the same amounts of 1-day old male chickens are killed and destroyed at the hatcheries each year.

\section{Meat, Other}

Side flow: $0.7 \%+3.3 \%$ (rearing phase), Food waste: $0.7 \%$. We calculated the meat side flow average by weighting the side flow percentages of bovine, pig and poultry by the amounts consumed in Finland, Sweden, Norway and Denmark. The meat side flow averages varied between $4.5-3.4 \%$. We used $4 \%$ as a rough standard estimate of "Meat, other lost in production. We used the same methodology to calculate food waste averages and chose $0.7 \%$ as a rough estimate of "Meat, other" food waste according to the FUSIONS definition. Since $0.7 \%$ represents losses after the rearing phase we calculated that, of the $4 \%$ side flow, $3.3 \%$ represents the rearing phase $(4.0-0.7=3.3)$.

\section{Offal}

Side flow: $0.7 \%+2.3 \%$ (rearing phase), Food waste: $0.7 \%$. Estimated to be same as "Meat, other".

\section{Fats, Animals, Raw}

Side flow: $0.7 \%+2.3 \%$ (rearing phase), Food waste: $0.7 \%$. Estimated to be same as "Meat, other". 


\subsubsection{Milk, eggs}

\section{Milk}

Side flow: $0.3 \%$, Food waste: $0.3 \%$. Based on interviews of 17 Swedish farmers from the western part of Sweden, $0.32 \%$ of the milk was thrown away mainly due to residues of antibiotics in milk (Bergman 2012 in Franke et al., 2013). Additionally, $3 \%$ of milk was fed to calves, but it was not included in the side flow since it was intended for this use. According to a Finnish study based on questionnaires answered by nine dairy farmers and interviews of six experts/farmers the side flow (milk that was disposed of) was estimated as $0.5 \%$ (Hartikainen et al., 2014). We used a more conservative standard estimate of $0.3 \%$ as the estimate of milk side flow. We used $0.3 \%$ as a rough estimate of milk food waste according to the FUSIONS definition.

\section{Butter, Ghee}

Side flow: 0.3\%, Food waste: $0.3 \%$. Estimated to be same as "Milk".

\section{Cream}

Side flow: 0.3\%, Food waste: $0.3 \%$. Estimated to be same as "Milk".

\section{Eggs}

Side flow: $3.6 \%$, Food waste: $3.6 \%$. According to a Swedish study (data from 45 egg producers) $3.6 \%$ of eggs is lost due to quality deviations (Hollstedt, 2011). We used 3.6\% as a rough standard estimate of egg food waste according to the FUSIONS definition.

\subsubsection{Fish, seafood}

\section{Fish, caught (wild fish):}

Side flow: $0.7 \%+$ missing (fish discards during fishing), Food waste: $0.7 \%$. According to the FUSIONS definition only fish caught and ready to be slaughtered (on the spot) are included within the system boundaries. A Norwegian study (Bleie and Skrudland 2014) estimated that $0.7 \%$ of fish is rejected at slaughter. We estimate the rejection percentage to be the same for wild fish, therefore around $0.7 \%$ is considered food waste according to the FUSIONS definition. This figure $(0.7 \%)$ also represents side flow after catching fish, and data on discarded fish during fishing is missing. 


\section{Farmed fish:}

Side flow: $0.7 \%+1.9 \%$ (rearing phase), Food waste: $0-7 \%$. Norwegian Fisheries Directorate creates regular statistics on fish deaths and discards within the Norwegian fish farming. In addition, a detailed study was done in 2013-2014 by Mattilsynet, the Norwegian Food Safety Authority. According to Mattilsynet (Bleie and Skrudland 2014) 16-18\% of fish are lost in primary production which corresponds around $2.6-2.7 \%$ in biomass (Svanes 2015). According to a Finnish questionnaire answered by 13 rainbow trout farmers the rainbow trout side flow varied between 0.5 and $11 \%$, and the average is $5.6 \%$ (results of this project). We used a more conservative standard estimate of $2.6 \%$ as the estimate of fish meat lost in production. Around $0.7 \%$ is considered to be food waste according to the FUSIONS definition (see "Fish, caught"). Since $0.7 \%$ represents losses after rearing phase we calculated that of the $2.6 \%$ side flow $1.9 \%$ represents rearing phase $(2.6-0.7=1.9)$.

\section{Seafood}

Side flow: missing, Food waste: missing.

\section{Fish oil}

Side flow: missing, Food waste: missing.

\subsection{Discussion of side flows and food waste}

The total side flow excluding the rearing phase for Finland, Sweden, Norway and Denmark is 804 thousand tonnes and the side flow of the rearing phase is 118 thousand tonnes. Thus, the side flow excluding the rearing phase is on average $3.2 \%$ and the side flow of the rearing phase is $0.5 \%$. Moreover, food waste (FUSIONS report definition) is 335 thousand tonnes in total, which totals $1 \%$ of production.

The amount of side flow versus total food production (edible parts of food) for each country is 3.7\% + 0.3\% (rearing phase) in Finland, $4.6 \%+$ $0.3 \%$ (rearing phase) in Sweden, $2.0 \%+0.6 \%$ (rearing phase) in Norway and $2.8 \%+0.6 \%$ (rearing phase) in Denmark. The amounts of food waste versus total food production (edible and inedible parts of food) are: $1.1 \%$ in Finland, $1.1 \%$ in Sweden, $1.1 \%$ in Norway and $0.9 \%$ in Denmark. We used standard side flow estimates (\%) and of food waste estimates (\%) for all four countries, and thus there are differences in relative amounts of side flow and food waste only because of the country specific differences in production profiles. 
Some product categories have a higher impact to the final figures than other product categories. For instance, both production volumes and side flow estimates of wheat are high, therefore the standard estimate of wheat has a significant impact on the absolute side flow amounts. This is demonstrated in Figure 2, where we used three different standard estimates of wheat side flow $(5 \%, 14 \%$ and $23 \%)$ for Finland, Sweden, Norway and Denmark. Figure 4 shows that, while keeping other standard estimates constant, the total sum of side flows of the four Nordic countries increases by 300 thousand tonnes solely when the standard estimate of wheat side flow changes from $5 \%$ to $23 \%$. Figure 4: Demonstrating the effect of uncertainty of the chosen standard estimate of side flow
(5\%, 14\% and $23 \%$ respectively for wheat). Left: "Sum of wheat side flows in the Nordic countries". Right: "Sum of total side flow in the Nordic countries"

\section{Tonnes of side flow}

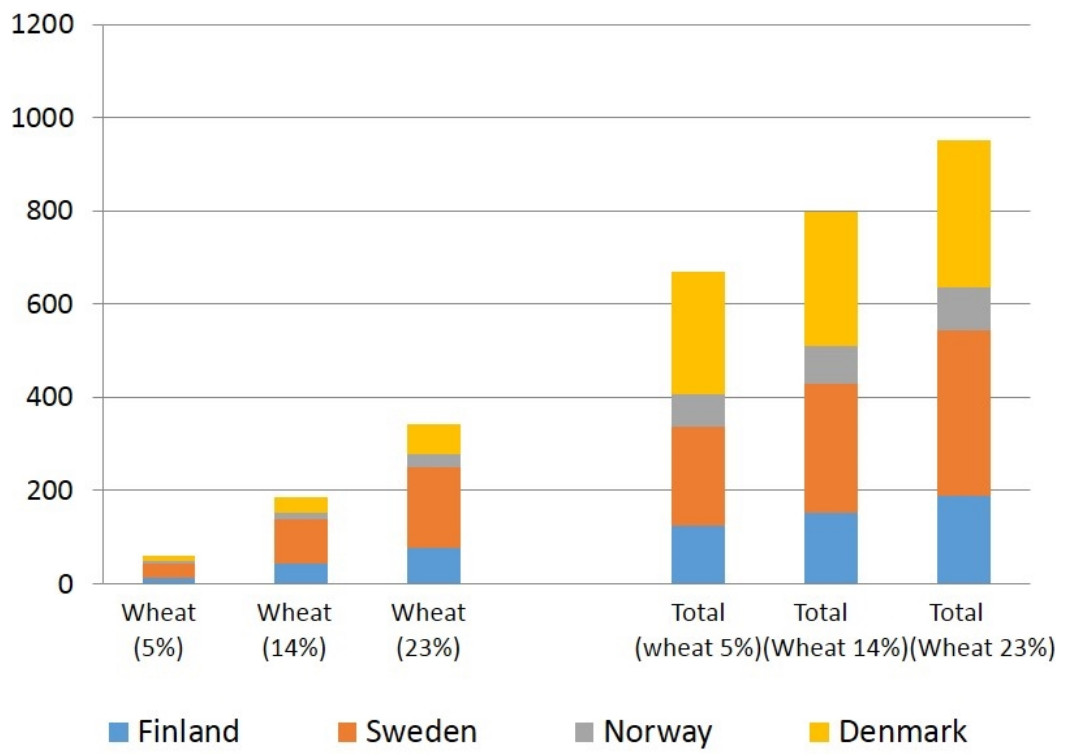

Altogether, due to several uncertainties and simplifications, one should consider these figures and standard estimates as rough estimates.

The conclusions and further recommendations regarding our calculations are:

- Primary production statistics (FAOSTAT) also include other production besides food production and do not specify the original intention of the production (e.g. the amount that is originally intended for food). We estimated how much of the cereals, starchy roots (thus 
potatoes), oil crops, and fish were used for food, but more sophisticated and consistent approaches are needed to define how much of the production is intended for food in all product categories.

- While we only included the part of production statistics that is intended for human consumption (corrections to the production volumes of cereals, starchy roots (thus potatoes), oil crops, and fish), and excluded the part of production that is used for e.g. feed from the production figures (Table 2), we did not exclude feed use from the side flow percentages (Table 4) and we calculated the total yield as: production + side flow, where side flow includes other uses e.g. feed use. This is because we consider feed use of food production (i.e. production that was intended for human consumption) as side flow. Consequently, the used side flow percentages can be somewhat distorted. All in all, the chosen methods have their weaknesses and should be considered to be the first attempts to estimate side flows in the food chain.

- It should be also noted that side flow - and food waste figures - do not include all the potential food that could be turned into human food. For instance, the side products of egg production are laying hens and day-old male chickens that are culled at the hatchery when sex is determined, but if hens and male chickens are not intended for human food, they should not be considered part of food production. However, this presents a significant figure, because according to a Swedish study up to $33 \%$ of laying hens are either disposed of or used as mink feed, mainly because the current transportation regulations stop the farmers from the Northern part of Sweden from sending their hens to slaughter (Jordbruksverket 2016).

- Whilst the data on side flows in primary production increases, the available data is scarce and uncertainties about the available data are significant, especially the lack of country-specific data and data on uses of side flow.

- Production systems and other circumstances (e.g. markets) can be quite different between the four countries, and thus our assumption to use standard estimates for side flow and food waste for all four countries is a very weak assumption.

- In the present study we cannot compare countries to each other because of the uncertainties listed above and because the differences between countries in the present study only reflect differences in production quantities. Consequently, there is a need to get a better understanding of product- and country-specific side flow and food 
waste amounts to improve the current estimates. Our further suggestions on how to conduct more specific data collection methods are presented in Chapter 6.

- Side flow also includes contaminated produce that is no longer suitable for human consumption, and part of the side flow is still edible food that is wasted in primary production. Therefore how the quality of the side flow is considered and addressed should be taken into consideration in future studies, especially when seeking the best practices to reduce side flows. 


\section{Case studies}

We carried out case studies for seven products in order to develop and test side flow quantification methods and to get results for relative side flow amounts for the products. The products studied were carrots, onions, wheat, rye, green peas, field peas, and cultivated rainbow trout/char. The geographical area was Finland, Sweden, Norway and Denmark. The main methods used were questionnaires, direct in-field measurements and interviews. Interviews were not used to quantify side flow amounts but to gain insight into reasons for side flow and for development and quality assurance of the questionnaires.

The main results are represented below as the averages from the different questionnaire studies in different countries. All products were not studied in all countries. In a few cases a range is given rather than a single number. These ranges do not represent uncertainty but averages from different production technologies. More detailed results, data sources and methodology are represented in this chapter. The uncertainty of the results is likely to be quite high, largely because of the low sample size. The standard deviation given in the results tables gives some indication of uncertainty but also includes the effect of natural variation between e.g. farms, geographical areas, and technologies.

Questionnaire results: Side flow amounts, individual country averages in $\%$ of total production ready for harvest

- Carrots: 17.6

20.8

25.8

13-31

- Onions: 8.4

11.4

21

$17-33$

- Green peas: 17.6

- Field peas: 16.5

- Rye: 4.2

- Wheat: 5.0

- Rainbow trout/char 
Harvest side flow measurements, country average(s)\% of total amount ready for harvest

- Carrots: 4.2

6.2

- Onions: 2.4

- Wheat: 1.4

- Field peas: 5.0

One important goal of this study was to get an estimate of the total side flow amount in the primary production of the four Nordic countries. Based on this goal and the need to test methodologies for quantifying side flow amounts for individual products, a number of selected case products, important to Nordic Countries' primary production, were studied. The selection was based on a set of criteria.

One important criterion was that the products were economically important products, hence high volume products in the Nordic area were prioritised for this study. The products also needed to be sufficiently different from each other to get a better understanding of side flow issues, especially amounts and reasons. Another important aspect was to choose different case products from what have been previously studied (e.g. Finland studied rye side flow since Finland had already studied wheat side flow quite recently) in order to get more representative data on total primary production side flows. On the other hand, we also chose to study the same products that have been studied previously using different study methods, and thus to enable method comparisons.

No meat products were studied in the case studies, although these products are high volume products and of large economic importance. The reason was that there is good statistical data that can be used to calculate meat side flows in the Nordic Countries. The side flow consists of dead animals from birth until they are delivered to the slaughter house. This means that we did not see meat side flow quantification as a methodological challenge in the Nordic Countries. The main motivation for the case studies was not to quantify side flows, but to develop a methodology for side flow quantification. 
Table 6: Overview of case studies in the project.

\begin{tabular}{ll} 
Products & Methods applied \\
Carrots & Questionnaires (DK, F, N, S), Interviews and field studies (F, N) \\
Onions & Questionnaires (DK, F, N, S), field studies (S), Interviews (S, F) \\
Green peas & Questionnaires (DK, F, N, S), Field studies field pea (F), Interviews (S, F) \\
Field peas & Questionnaires (DK, F, S), field study (F), interviews (F) \\
Wheat & Questionnaires (DK, F, N, S), Interviews (F), Field study (F) \\
Rye & Questionnaires (F), Interviews (F) \\
Aquaculture Rainbow trout & Questionnaires (F, DK, S), Interviews (F) \\
Char & Questionnaires (S) \\
\hline
\end{tabular}

\subsection{Results}

The results from the questionnaires, the field studies and the interviews are summarised in the tables below.

\subsubsection{Questionnaire results}

Side flow quantification was the main target for the questionnaires, but questions on the reasons for side flow and possible reduction measures, or better side flow utilisation, were included in the questionnaires to give added value. 
Table 7: Questionnaire results for carrots

\begin{tabular}{|c|c|c|c|c|c|}
\hline Country & $\begin{array}{l}\text { Response rate } \\
\text { (of all who } \\
\text { received the } \\
\text { question- } \\
\text { naire) }\end{array}$ & $\begin{array}{l}\text { Side flow } \\
\text { amount (standard } \\
\text { deviation) }\end{array}$ & $\begin{array}{l}\text { Side flow treatment } \\
\text { (of total side flow) }\end{array}$ & Reasons & $\begin{array}{l}\text { Side flow reduction and } \\
\text { measures for better side flow } \\
\text { utilisation }\end{array}$ \\
\hline Denmark & $32 \%$ & $20.8 \%$ & $\begin{array}{l}10 \% \text { left in the field, } \\
61 \% \text { used for animal } \\
\text { feed, } 25 \% \text { com- } \\
\text { posted, } 4 \% \text { other. }\end{array}$ & $\begin{array}{l}\text { Quality issues, pests, } \\
\text { plant diseases, har- } \\
\text { vesting methods. }\end{array}$ & No answers \\
\hline Finland & $10 \%$ & $25.8 \%(15 \%)$ & $\begin{array}{l}\text { Three major usages: } \\
\text { Composted, animal } \\
\text { feed, left in field. }\end{array}$ & $\begin{array}{l}\text { Most important: Af- } \\
\text { ter harvest: Quality } \\
\text { (appearance, size), } \\
\text { plant diseases and } \\
\text { damages. During har- } \\
\text { vest: Weather condi- } \\
\text { tions, plant diseases } \\
\text { and harvesting proce- } \\
\text { dures. }\end{array}$ & $\begin{array}{l}\text { Finding ways to overcome } \\
\text { small-scale problems, finding } \\
\text { new markets, feeding side flow } \\
\text { to animals (no impact to side } \\
\text { flow amount). }\end{array}$ \\
\hline Norway & $23 \%$ & $17.6 \%(4.6 \%)$ & $\begin{array}{l}25.5 \% \text { left in the } \\
\text { field, } 66 \% \text { used for } \\
\text { animal feed, } 8.5 \% \\
\text { other. }\end{array}$ & $\begin{array}{l}\text { Pests, plant diseases } \\
\text { and quality issues are } \\
\text { the main reasons. }\end{array}$ & $\begin{array}{l}\text { Improved agronomical tech- } \\
\text { niques and quality/better utili- } \\
\text { sation/better sorting. }\end{array}$ \\
\hline Sweden & $35 \%$ & $\begin{array}{l}13-31 \% \text { (different } \\
\text { storage time and } \\
\text { storage practice) }\end{array}$ & $\begin{array}{l}51 \% \text { animal feed, } \\
16 \% \text { bioenergy or de- } \\
\text { posited, } 15 \% \text { brought } \\
\text { back to the field, } \\
9 \% \text { not harvested, } \\
9 \% \text { other use. }\end{array}$ & $\begin{array}{l}\text { Main harvest side } \\
\text { flow reasons: Unac- } \\
\text { ceptable size and } \\
\text { shape, damage at } \\
\text { harvest and handling, } \\
\text { insect or animal dam- } \\
\text { age. } \\
\text { Main post-harvest } \\
\text { side flow reasons: } \\
\text { Unacceptable size } \\
\text { and shape, unac- } \\
\text { ceptable appearance, } \\
\text { damage at handling. }\end{array}$ & $\begin{array}{l}\text { Less demanding quality stand- } \\
\text { ards, improved plant protec- } \\
\text { tion, and changes in consumers } \\
\text { and retailers attitudes towards } \\
\text { acceptable quality. }\end{array}$ \\
\hline
\end{tabular}


Table 8: Questionnaire results for onions

\begin{tabular}{|c|c|c|c|c|c|}
\hline Country & $\begin{array}{l}\text { Response } \\
\text { rate (of all } \\
\text { growers) }\end{array}$ & $\begin{array}{l}\text { Side flow } \\
\text { amount (stand- } \\
\text { ard deviation) }\end{array}$ & $\begin{array}{l}\text { Side flow treatment } \\
\text { (of total side flow) }\end{array}$ & Reasons & $\begin{array}{l}\text { Side flow reduction and } \\
\text { measures for better side } \\
\text { flow utilisation }\end{array}$ \\
\hline Denmark & $41 \%$ & $21 \%$ & $\begin{array}{l}\text { Insufficient data for } \\
\text { quantity but main } \\
\text { uses are compost- } \\
\text { ing, bioenergy, re- } \\
\text { turned to field and } \\
\text { not harvested. }\end{array}$ & $\begin{array}{l}\text { Quality issues, } \\
\text { plant diseases, } \\
\text { pests and weather } \\
\text { conditions. }\end{array}$ & $\begin{array}{l}\text { Improved storage, con- } \\
\text { sumers/retail accepting } \\
\text { different sizes and differ- } \\
\text { ent shapes and colours, } \\
\text { better cultivars and better } \\
\text { agronomy }\end{array}$ \\
\hline Finland & $10 \%$ & $11 \%(11 \%)$ & $\begin{array}{l}\text { Composted/bio } \\
\text { waste and left in the } \\
\text { field are the major } \\
\text { reasons. }\end{array}$ & $\begin{array}{l}\text { Diseases and dam- } \\
\text { age, quality, ap- } \\
\text { pearance. }\end{array}$ & $\begin{array}{l}\text { Improved agronomical } \\
\text { techniques, prevention of } \\
\text { plant diseases, improved } \\
\text { storage, finding ways to } \\
\text { overcome small-scale } \\
\text { problems }\end{array}$ \\
\hline Norway & $32 \%$ & $8.4 \%$ (6.1\%) & $\begin{array}{l}5 \% \text { not harvested, } \\
32 \% \text { composted, and } \\
50 \% \text { not used. (\#) }\end{array}$ & $\begin{array}{l}\text { Pests, plant dis- } \\
\text { eases and quality } \\
\text { reasons are the } \\
\text { main reasons. }\end{array}$ & $\begin{array}{l}\text { Accept deviating size and } \\
\text { appearance and better ag- } \\
\text { ronomical practices are } \\
\text { the main measures. }\end{array}$ \\
\hline Sweden & $36 \%$ & $\begin{array}{l}17 \% \text { (ordinary } \\
\text { storage onions) } \\
18 \% \text { (fresh in } \\
\text { bunches) } \\
33 \% \text { (for food } \\
\text { industry) }\end{array}$ & $\begin{array}{l}36 \% \text { back in field, } \\
28 \% \text { compost, } \\
19 \% \text { not harvested, } \\
7 \% \text { bioenergy, } \\
5 \% \text { other use. }\end{array}$ & $\begin{array}{l}\text { Damage at har- } \\
\text { vest or handling; } \\
\text { unacceptable size, } \\
\text { shape and appear- } \\
\text { ance; diseases in } \\
\text { the fields are the } \\
\text { main reasons. }\end{array}$ & $\begin{array}{l}\text { Less strict quality criteria } \\
\text { and size restrictions is the } \\
\text { most important measure. } \\
\text { Less mechanical dam- } \\
\text { age/better handling, bet- } \\
\text { ter plant protection are } \\
\text { also mentioned. }\end{array}$ \\
\hline
\end{tabular}


Table 9: Questionnaire results for peas

\begin{tabular}{|c|c|c|c|c|c|}
\hline Country & $\begin{array}{l}\text { Response } \\
\text { rate (of all } \\
\text { growers) }\end{array}$ & $\begin{array}{l}\text { Side flow } \\
\text { amount } \\
\text { (standard de- } \\
\text { viation) }\end{array}$ & $\begin{array}{l}\text { Side flow treatment } \\
\text { (of total side flow) }\end{array}$ & Reasons & $\begin{array}{l}\text { Side flow reduction and } \\
\text { measures for better side flow } \\
\text { utilization }\end{array}$ \\
\hline $\begin{array}{l}\text { Denmark } \\
\text { (Green and } \\
\text { field peas) }\end{array}$ & $25 \%$ & $18 \%$ & $\begin{array}{l}\text { Not harvested }(59 \%) \text {, } \\
\text { bioenergy }(30 \%) \text {, } \\
\text { compost }(25 \%) \text {, re- } \\
\text { turned to field ( } 8 \%) \text {, } \\
\text { other }(25 \%)(\#) .\end{array}$ & $\begin{array}{l}\text { Damage during harvest } \\
\text { and handling, no sale/- } \\
\text { overproduction, weather } \\
\text { conditions, other quality } \\
\text { parameters and damage } \\
\text { from animals are the main } \\
\text { reasons given. }\end{array}$ & $\begin{array}{l}\text { Main reasons given: } \\
\text { Higher sales/better prices, im- } \\
\text { proved agronomy, e.g. new } \\
\text { pesticides, better harvest tech- } \\
\text { niques, } \\
\text { not possible, better weather. }\end{array}$ \\
\hline $\begin{array}{l}\text { Finland } \\
\text { (Green } \\
\text { peas) }\end{array}$ & $11 \%$ & $17.6 \%(22.7 \%)$ & $\begin{array}{l}\text { Mostly left in the } \\
\text { field, some used for } \\
\text { animal feed. }\end{array}$ & $\begin{array}{l}\text { Diseases and weather con- } \\
\text { ditions. }\end{array}$ & $\begin{array}{l}\text { Finding ways to overcome } \\
\text { small scale problem, finding } \\
\text { new markets. }\end{array}$ \\
\hline $\begin{array}{l}\text { Sweden } \\
\text { (Green } \\
\text { peas) }\end{array}$ & $67 \%$ & $\begin{array}{l}21.4 \% \text { (stand- } \\
\text { ard deviation } \\
\text { between farm- } \\
\text { ers not known) }\end{array}$ & $\begin{array}{l}\text { Except for the unhar- } \\
\text { vested part, which } \\
\text { was left in the field, } \\
\text { side flows where } \\
\text { used to produce bio- } \\
\text { energy. }\end{array}$ & $\begin{array}{l}\text { Major reasons are har- } \\
\text { vesting and handling and } \\
\text { did not have enough time } \\
\text { to harvest all. } \\
\text { Other reasons include } \\
\text { weather conditions, wrong } \\
\text { size and appearance, agri- } \\
\text { cultural problems. }\end{array}$ & $\begin{array}{l}\text { Better harvest and process ma- } \\
\text { chinery, better cultivars, better } \\
\text { (more environmentally } \\
\text { friendly) pesticides and better } \\
\text { market prices. }\end{array}$ \\
\hline $\begin{array}{l}\text { Norway } \\
\text { (Green } \\
\text { peas) }\end{array}$ & $\begin{array}{l}\text { One pro- } \\
\text { cessor rep- } \\
\text { resenting } \\
\text { several } \\
\text { farmers. }\end{array}$ & $\begin{array}{l}20.1 \% \text { (stand- } \\
\text { ard deviation } \\
\text { between farm- } \\
\text { ers not known) }\end{array}$ & $\begin{array}{l}\text { Animal feed: } 75 \% \text {. } \\
\text { Compost: } 20 \% . \\
\text { Not harvested: } 5 \% \text {. }\end{array}$ & $\begin{array}{l}\text { Major reason was } \\
\text { weather. Colour or ap- } \\
\text { pearance also important. } \\
\text { Other reasons insect/ani- } \\
\text { mal. damage and agro- } \\
\text { nomical issues. }\end{array}$ & $\begin{array}{l}\text { Better pesticides against } \\
\text { aphids. }\end{array}$ \\
\hline $\begin{array}{l}\text { Finland } \\
\text { (Field peas) }\end{array}$ & $11 \%$ & $17.7 \%(16.7 \%)$ & $\begin{array}{l}\text { Mostly used for ani- } \\
\text { mal feed, some left in } \\
\text { field, "other use". }\end{array}$ & $\begin{array}{l}\text { Diseases and weather con- } \\
\text { ditions. }\end{array}$ & $\begin{array}{l}\text { Improved agronomical tech- } \\
\text { niques, finding ways to over- } \\
\text { come small scale problem, find- } \\
\text { ing new markets, feeding side } \\
\text { flow to animals (no impact to } \\
\text { side flow amount) }\end{array}$ \\
\hline $\begin{array}{l}\text { Sweden } \\
\text { (Field peas) }\end{array}$ & $39 \%$ & $\begin{array}{l}16.5 \% \text { (aver- } \\
\text { age of two } \\
\text { buyers: } 8 \% \text { and } \\
25 \% \text { ). Standard } \\
\text { deviation not } \\
\text { between farm- } \\
\text { ers not known. }\end{array}$ & $\begin{array}{l}\text { Used for animal feed, } \\
\text { remaining in field and } \\
\text { used for bioenergy } \\
\text { and compost. }\end{array}$ & $\begin{array}{l}\text { Damage during harvest or } \\
\text { handling, insect/wildlife } \\
\text { damage, quality (bad col- } \\
\text { our/appearance). }\end{array}$ & $\begin{array}{l}\text { Better varieties, better agro- } \\
\text { nomical techniques or equip- } \\
\text { ment, decrease effect of wild- } \\
\text { life. }\end{array}$ \\
\hline
\end{tabular}


Table 10: Questionnaire results for cereals

\begin{tabular}{|c|c|c|c|c|c|}
\hline Country & $\begin{array}{r}\text { Re- } \\
\text { sponse } \\
\text { rate (of } \\
\text { all grow- } \\
\text { ers) }\end{array}$ & $\begin{array}{r}\text { Side flow } \\
\text { amount } \\
\text { (standard } \\
\text { deviation) }\end{array}$ & $\begin{array}{l}\text { Side flow treatment } \\
\text { (of total side flow) }\end{array}$ & Reasons & $\begin{array}{l}\text { Side flow reduction } \\
\text { and measures for } \\
\text { better side flow uti- } \\
\text { lisation }\end{array}$ \\
\hline $\begin{array}{l}\text { Finland } \\
\text { (rye) }\end{array}$ & $14 \%$ & $4.2 \%(12.9 \%)$ & $\begin{array}{l}\text { Mostly animal feed, } \\
\text { some left in the } \\
\text { field. }\end{array}$ & $\begin{array}{l}\text { Harvesting tech- } \\
\text { nique, weather } \\
\text { conditions and } \\
\text { quality problems. }\end{array}$ & $\begin{array}{l}\text { Improved agronomi- } \\
\text { cal techniques, pre- } \\
\text { venting the yield } \\
\text { from ergot (sac } \\
\text { fungi), finding new } \\
\text { uses for the side } \\
\text { flow, finding ways to } \\
\text { overcome small } \\
\text { scale problem, feed- } \\
\text { ing side flow to ani- } \\
\text { mals (no impact to } \\
\text { side flow amount). }\end{array}$ \\
\hline $\begin{array}{l}\text { Denmark } \\
\text { (wheat) }\end{array}$ & $33 \%$ & $5 \%$ & $\begin{array}{l}\text { The majority used } \\
\text { for feed, small } \\
\text { amounts remain in } \\
\text { field or is used for } \\
\text { other purpose. }\end{array}$ & $\begin{array}{l}\text { Quality deficien- } \\
\text { cies (e.g. protein } \\
\text { and starch quality) } \\
\text { was the main } \\
\text { cause followed by } \\
\text { plant diseases, } \\
\text { thrashing and } \\
\text { weather condi- } \\
\text { tions. }\end{array}$ & $\begin{array}{l}\text { Increased nitrogen } \\
\text { fertilization, more } \\
\text { pesticide use, im- } \\
\text { proved storage, bet- } \\
\text { ter cultivars and re- } \\
\text { duction in competi- } \\
\text { tive disadvantage. }\end{array}$ \\
\hline $\begin{array}{l}\text { Norway } \\
\text { (wheat) }\end{array}$ & $15.6 \%$ & $6.6 \%(20 \%)$ & $\begin{array}{l}\text { Mostly used for ani- } \\
\text { mal feed. In addi- } \\
\text { tion, some left in the } \\
\text { field. }\end{array}$ & $\begin{array}{l}\text { Weather condi- } \\
\text { tions, quality is- } \\
\text { sues and pests/an- } \\
\text { imal damage ma- } \\
\text { jor reasons. }\end{array}$ & $\begin{array}{l}\text { Economic incentives, } \\
\text { little can be done } \\
\text { since weather is the } \\
\text { main reason, im- } \\
\text { proved cultivars, and } \\
\text { improved agronomy. }\end{array}$ \\
\hline $\begin{array}{l}\text { Sweden } \\
\text { (wheat) }\end{array}$ & $20 \%$ & $23 \%$ & $\begin{array}{l}39 \% \text { is lost, } 44 \% \\
\text { used for animal } \\
\text { feed, } 4 \% \text { heating } \\
\text { and fuel, } 13 \% \text { other } \\
\text { purposes. }\end{array}$ & $\begin{array}{l}\text { Major reasons are } \\
\text { low protein con- } \\
\text { tent and damage } \\
\text { due to animal } \\
\text { wildlife. Other rea- } \\
\text { sons are harvest, } \\
\text { weather, and low } \\
\text { falling number. }\end{array}$ & Not investigated. \\
\hline
\end{tabular}


Table 11: Field study results of harvest losses

\begin{tabular}{|c|c|c|c|c|c|c|}
\hline Product & Country & Result & $\begin{array}{l}\text { Standard } \\
\text { Deviation }\end{array}$ & $\begin{array}{l}\text { Number of } \\
\text { farmers/ } \\
\text { individual } \\
\text { fields }\end{array}$ & Side flow reasons & Possible reduction measures \\
\hline Carrot & Norway & $4.2 \%$ & $2.5 \%$ & $8 / 12$ & $\begin{array}{l}\text { Harvester adjustment and } \\
\text { manoeuvring, cultivar } \\
\text { choice, size of field, size of } \\
\text { headland. }\end{array}$ & $\begin{array}{l}\text { Better adjustment of har- } \\
\text { vesters, optimal driving } \\
\text { speed, better cultivars. }\end{array}$ \\
\hline Carrot & Finland & $6.2 \%$ & $2.0 \%$ & $3 / 6$ & $\begin{array}{l}\text { Plant diseases and moulds } \\
\text { during storage because of } \\
\text { weather, crop rotation, } \\
\text { storage conditions and cul- } \\
\text { tivar. Also small quality de- } \\
\text { ficiencies was mentioned } \\
\text { as major reasons for post- } \\
\text { harvest losses. }\end{array}$ & \\
\hline Onion & Sweden & $2.4 \%$ & Not given. & $8 / 24$ & $\begin{array}{l}\text { Small size onions left in } \\
\text { field due to how the har- } \\
\text { vester was adjusted. } \\
\text { Onion piles found in field } \\
\text { caused by the gap be- } \\
\text { tween two wagons behind } \\
\text { the tractor. } \\
\text { Parts of the field not har- } \\
\text { vested because it was wa- } \\
\text { terlogged and difficult to } \\
\text { harvest. }\end{array}$ & \\
\hline Wheat & Finland & $1.4 \%$ & $1.5 \%$ & $3 / 5$ & $\begin{array}{l}\text { Weather, animal damage, } \\
\text { harvesting conditions, har- }\end{array}$ & $\begin{array}{l}\text { Careful harvesting, adjust- } \\
\text { ment of harvester for every }\end{array}$ \\
\hline Field pea & Finland & $4.9 \%$ & $0.2 \%$ & $2 / 3$ & $\begin{array}{l}\text { vester adjustment, driving } \\
\text { speed, use of side cutter } \\
\text { (field pea) and reasons re- } \\
\text { lated to field conditions } \\
\text { and cultivation methods. }\end{array}$ & $\begin{array}{l}\text { plot, straight driving line, se- } \\
\text { lection of field plot, maintain } \\
\text { growing conditions, cultiva- } \\
\text { tion method factors like crop } \\
\text { rotation, improved crop pro- } \\
\text { tection and weed protection, } \\
\text { work scheduling. }\end{array}$ \\
\hline
\end{tabular}

\subsubsection{Field study results}

Quantification was the main focus for the field studies. It was assumed that the products would be left in the field, hence no investigations were made about waste treatment. The researchers who carried out the studies made some observations about side flow reasons, but most information on side flow reasons and reduction possibilities came from interviews and questionnaires. 


\subsection{Discussion on case studies}

The questionnaire, interview and field study results indicate a large variation in side flow amounts from year to year, across geographical areas and between individual producers. The latter is indicated by a rather large standard deviation in the questionnaire results. It is not clear how much of this variation is "real" variation, how much is related the uncertainty of farmers not knowing exactly how much side flow they have (overall the farmers do not keep a record on the amounts of side flows, end-uses of the side flows or reasons for the side flows) and how much stems from the methods used to gather and process information. It is likely that the uncertainty of the results is high, but our data does not allow a quantification of this uncertainty. When we look at side flow treatment and side flow reasons the results are less variable than when considering side flow amounts.

\subsubsection{Uncertainty of results}

Sample size was one of the big problems we encountered in this study. This problem was especially pronounced for the field studies where the sample size was very small. However, the study sample size was also an issue for the questionnaire studies. Filling out the questionnaire was not obligatory and this was reflected in the low response rates in relation to what is needed to get statistically significant results. Appendix 1 includes an example of a Finnish questionnaire that had too few responses for it to represent statistically valid results. This problem not only concerns the Finnish questionnaire, but all questionnaires. Another problem was that the questions were misunderstood by some of the respondents, resulting in illogical or conflicting answers, e.g. when numbers in a mass balance did not add up to $100 \%$. Furthermore, not all the respondents had access to the information we asked, therefore their answers might have only been estimates.

The numbers given in the questionnaire tables should not be interpreted as exact amounts but as initial estimates, meaning they do not have the scientific exactitude to be used to compare side flow amounts between Nordic Countries.

The system starts when crops are ready for harvest. In some questionnaires there are questions based on pre-harvest conditions, such as in the Swedish wheat questionnaire. However, the intention was not to quantify pre-harvest side flows but to find explanations for side flows occurring at harvest or later. 


\subsubsection{Field studies}

The main strength of the field studies was that it allowed direct observations by researchers, and the measurements could be done in a standardised and controlled way. In most of the other methods the researchers had to rely on data from others. In such cases we cannot be sure if the data was calculated or measured in the same way. Often it is not clear whether the numbers are based on estimates or measurements and how the estimates and measurements had been carried out. We assume, based on interviews and previous experience that most data are based on estimates,

The uncertainty of the field studies is quite high when considering the very limited sample that was studied and the high variability of side flow amounts. The number of fields in each study that were investigated was very low considering the large amount of total fields. Previous studies, interviews with farmers and statistics all show that variability from year to year can be high and the variation between farms in many cases is also high. The studies also showed large variations between fields, even in the same region and farmed by the same farmer. Furthermore, the studies showed large variations within a field. Because of these factors it would have been a big challenge to find a representative sample, and even if that challenge is overcome, it would be very difficult to investigate hundreds or thousands of fields every year. It would require too much resources and time. However, the procedure is relatively straightforward and could be interesting to many farmers. Thus it might be possible to persuade a limited number of farmers to measure a few fields every year.

The important question is whether the results are good enough in relation to possible uses. In our opinion the results are indicative of the magnitude of the side flows for these products. We can conclude that the side flow for Norwegian carrots is approximately $4-5 \%$, and less likely to be $1 \%$ or $10 \%$. However, the results for all field studies are much too uncertain to compare side flows from year to year, unless the study is for very small populations, such as one field.

\subsubsection{Reasons for side flow}

The reasons behind side flows cover several topics and also different levels of explanation. Apparent reasons (e.g. appearance), causal reasons (e.g. bad weather, diseases and pests) and underlying reasons (e.g. low prize, overproduction) were given by the farmers. Inferior quality is one major reason, whether this is based only on appearance ("cosmetic quality") or another reason, such as inferior protein quality. The studies indicate that the most common, and probably the most important, factor behind side flows are the 
causal reasons like weather, diseases and pests. When studying the side flows in detail one can see that underlying reasons such as price and the supply/demand relationship are also considerably important. These circumstances are often outside of the farmers" control. Several questionnaires contained open questions, with no fixed answers. We found that valuable insights into the reasons for side flows were gained through having open questions as part of several of the questionnaires.

It is not possible to compare data between countries for side flow reduction measures from the questionnaires because the questions were asked somewhat differently in each country. In Norway, Finland and Sweden we asked what could be done to reduce side flows, and in Denmark we asked what research was needed to reduce side flows. Additionally, in Finland the producers were asked about their willingness to find other uses for the side flows. All questions covered important topics such as side flow reduction measures, and they captured some different aspects of reduction possibilities.

\subsubsection{Side flow treatment}

Vegetable and pulse side flows are used mainly for animal feed when possible. Onions are not suitable for animal feed and are often composted. A significant part of the vegetables and pulses are not harvested, but rather left in the field to rot and serve as fertilizer. A part of the side flow is used for energy purposes, mostly dead fish but also some pulses. Wheat and rye side flows are mostly used for animal feed. A small proportion is used for energy purposes. For all product groups there is a proportion that is not used or land filled. 



\section{Development of methodology}

In this project, questionnaires, interviews and field studies where used as part of the case studies to gather information on side flows. In the Nordic side flow quantification study, data from scientific studies and statistics were used as well as information from the case studies.

\section{Questionnaires}

Main method used.

Advantage: Allows data collection from many actors with relatively high efficiency. This is the method that will most likely give statistically significant results.

Disadvantage: Higher uncertainty in the collected data than by direct measurement inside the sample, but since it is much easier to take a large sample, overall uncertainty will be lower. Less flexible than interviews because questions cannot be adapted for each case.

Lesson learned: Questionnaires must be adapted to the product studied, technology used, respondents (mostly farmers), organisation of primary production (who does what), context, etc. Questionnaires must be tested on test subjects before they are implemented.

Recommendation: These are the recommended method to use in cases where side flow data has been recorded or are known by farmers, but not publicly available, e.g. most plant crops.

\section{Interviews}

Used as a supporting method

Advantage: Good tool to get in-depth knowledge. High flexibility.

Disadvantage: Resource-intensive method. Higher uncertainty in the collected data than by direct measurement.

Lessons learned: This method works well to better understand side flow reasons and other issues connected with side flows. 
Recommendation: It is the recommended method when the number of actors is small. It is a valuable tool to support data and to help plan other research methods such as questionnaires, field studies and open-source data.

\section{Direct measurements}

Used to measure harvest side flow.

Advantage: Allow for precise measurements to be made.

Disadvantage: A very resource-intensive method. Difficult to use in cases where side flows are unevenly distributed because budget restrictions only allow for a few samples to be taken. Direct measurements are restricted to time and place, and require extremely careful planning and execution.

Lessons learned: In cases where variability is high, e.g. for field crop harvest side flows, large numbers of measurements are necessary in order to obtain statistically valid results. Because of the costs, it is very difficult to get statistically valid results.

Recommendation: Recommended method to for cases where there is no available data on side flows and the other methods cannot be used.

\section{Published data}

Used to find side flow amounts and total production amounts, the latter to calculate relative side flow amounts (side flow as a percentage of total production, see Chapter 3).

Advantage: Useful for scaling up side flow percentages to calculate total National side flow in primary production. Covers large parts, or the whole population of a country.

Disadvantage: Gives very little detail on side flow reasons and possible reduction measures. In cases where the production can be used for both food and nonfood purposes, the statistics do not give separate data on the intentions.

Lessons learned: Using statistical data is a good method for calculating side flows, but in many cases they require more information in order to be useful in a waste quantification study.

Recommendation: Recommended method in cases when statistical data is available, such as for cereals or meat side flows, and definitions and system boundaries align with goal and scope of the study. 


\subsection{Approach for side flow quantification}

FUSIONS suggests a general approach for quantification of food waste, see Figure 5.

Figure 5: General approach for food waste quantification in primary production

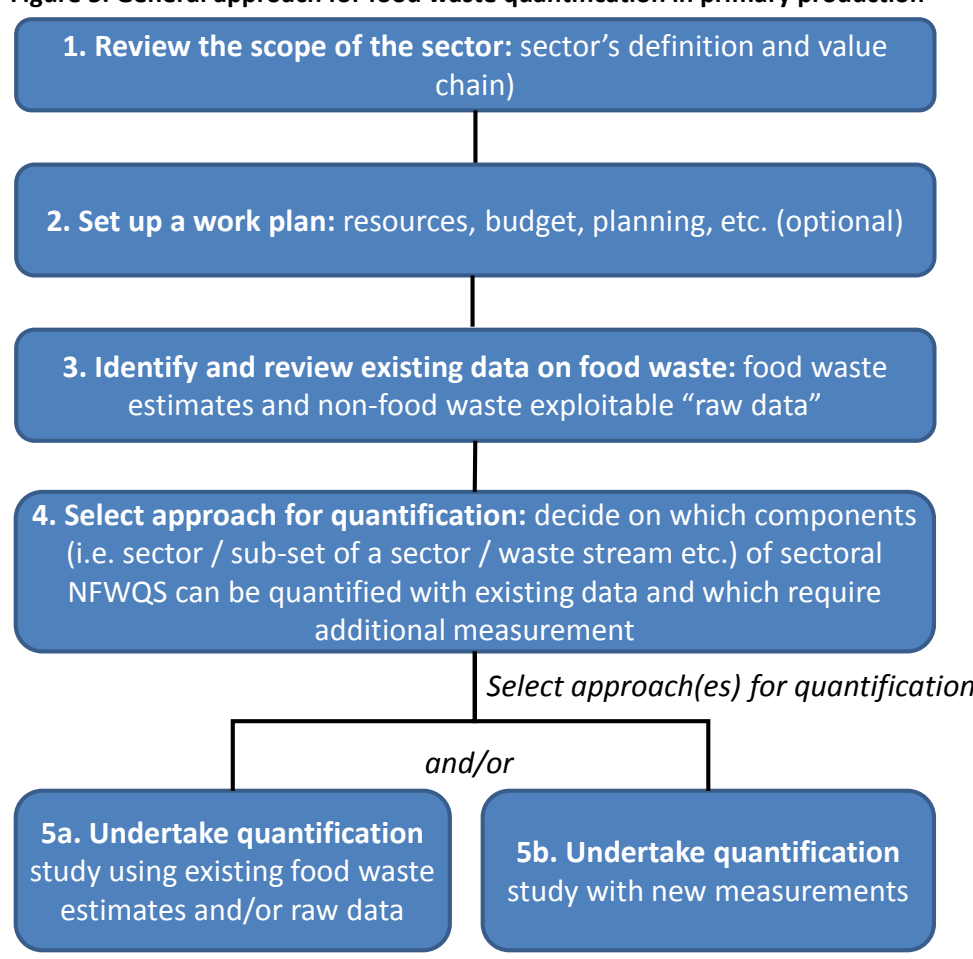

This approach also works for side flow quantification, and it can be used in cases where the study has additional goals. These goals could include finding reasons for side flows and/or identifying what can be done to reduce side flows or utilise them in a better way. In cases where other goals than quantification is relevant, the formulation of goals is the first step before scope review.

\subsection{Methods for side flow studies}

There are many methods that could theoretically be used for the study of side flows. There is currently no internationally accepted, "standard" way of quantifying side flows, although there are initiatives like the Food Loss and Waste Protocol (WRI 2015) and the FUSIONS food waste quantification manual. 
The following methods have been reviewed by FUSIONS:

- Measuring

- Scanning (bar code)

- Food waste diary

- Questionnaires

- Interviews

- Calculation from statistical data

- Mass balances (input vs output)

Scanning is a method where packaged products with a bar code are scanned after being sorted out as side flow. This method is most relevant in retail and wholesale. Mass balance is a method whereby product amounts entering and leaving a system are compared and the side flow is calculated as the difference between the two.

FUSIONS makes recommendations for which methods should be used for primary production. Scanning was excluded from the scope because it requires products to be packaged and have a barcode. The FUSIONS recommendations are different based on whether the purpose of the study is to make quantifications for EU-28 statistics (statistical data and mass balances), whether it is a basic study for improved insight, or if it's a study for internal prevention approaches. For the last two purposes, on-site measurements, food waste diaries, interviews and questionnaires were recommended.

\subsection{Choice of methods for side flow quantification}

The main methods used in this project were:

- Questionnaires

- Interviews

- Direct measurements

- Using published data, e.g. statistics

The reason for choosing these methods and for choosing how they would be adapted in this project was based on experiences gained in a previous Nordic project with the same project group (Franke et al., 2013), the participants' experiences from other projects and published studies, e.g. those collated by FUSIONS (Møller et al., 2014). Of the methods recommended by FUSIONS, a "food waste" diary and mass balances were not used. 
The main goal of this study was to develop and test side flow quantification methods. In order to quantify side flows we needed the following information from each unit (farm or other):

- side flows amounts (in absolute terms, in mass and/or volume)

- side flow treatment (in order to know whether the flow is a side flow/food waste)

- total production (to calculate relative side flow amounts in $\%$ of total production)

This is the minimum information needed for quantification. However, the ultimate target of any side flow study is to reduce side flows and thus increase the amount of food that is going to human consumption. In order to fulfil this target, the following issues should also be addressed in side flow quantification studies:

- side flows reasons

- side flow reduction possibilities

Before the methods could be developed and tested, an approach largely based on the decision tree from Figure 1 was drafted. In cases where a scientific study of side flows was available, e.g. for aquaculture salmon and trout in Norway, this method was preferred. If statistical side flow data was available and was of adequate quality, this was the second best option. In many cases, side flow data was recorded and/or known to the farmers but not publicly available. In cases where the amount of actors was high and variability of production is high, questionnaires were used. In cases where no records existed because no measurement had been done, and the involved actors gave poor estimates, direct measurements were used. Another motivation for the use of direct measurement was to try different methods for the same side flow, e.g. we had in a previous study used interviews to find harvest waste for carrots and now decided to use direct measurement to see how the methods compared.

It was decided to test the use of interviews in a supporting role, for quality assurance of questionnaires, to deepen the understanding the findings of direct measurements and to better understand side flow reasons. 


\subsubsection{Method choice vs. data availability}

The availability of data was an important factor when considering which method to use for quantification. This is especially important for the primary production since the data are usually scattered, due to the large number of producers. Additionally, the yields and side flow amounts varied greatly between producers and years since primary production relies on biological processes and because weather conditions are variable. Moreover, the primary producers might not have the necessary data or the data might not be readily available. Most of primary production occurs before the food enters the economic system. Typically, food enters the economic system when measurements are made to determine the quantity of the product in order to establish the correct payment. For several products this occurs at a late stage, e.g. carrots in Norway, where this occurs after sorting is done, and the amount of products in each quality class is determined.

Therefore, due to the characteristics of primary production:

- It is often necessary to gather a lot of data to be able to calculate a result that is representative for the whole population.

- It is often necessary to contact many actors involved in primary production, e.g. pack houses, companies that process grain or people hired for harvesting or for transport.

- One needs to prepare for high uncertainty.

Overall, this means that gathering data can be very time consuming and expensive. In many cases, sampling must be done, such as gathering data for only part of the population in study. Then one needs to make sure that the sample is representative of the entire population. Representativity implies that the sample represents the whole population in terms of e.g. time, technology, geography, farm size, and sample size of total population.

\subsubsection{Products with low availability}

Often the producer has no data or just a rough estimate on the side flow amounts. This is especially the case for harvest losses for open field cultivation of fruits, vegetables, berries and cereals (Franke et al., 2013). In such cases, direct measurements may be the only applicable method. In most cases it is unrealistic to ask the farmers to do the analyses themselves. They might be incentivised to do the analyses in some cases, but it is time-consuming work and may not be profitable to gather the produce 
lost on harvest. Another drawback is that it is often difficult to persuade farmers to conduct the measurements in a standardised way. Such studies would most likely be done by external personnel and will be resource intensive. On the other hand, such measurements allow for more detailed and unbiased observations.

\subsubsection{Products with high availability}

The opposite case occurs when the data needed for the calculation is openly available, e.g. in national statistics. Sometimes the statistics or other data will even cover entire populations. However, the data may not be in the right format for quantification. For instance, data might exist for animal or fish mortality during rearing, but usually only from a number of individuals in a certain age class. In these cases conversion factors are needed. Such calculations normally require small resource input because the data is already collected and cover large parts of the population. Sometimes the statistics do not cover the whole scope and information such as transport losses are missing.

Questionnaires and interviews are methods that are relevant for collecting data that is measured or estimated and recorded or known by the farmer. A typical estimate would be when farmers know how many bins are harvested and the approximate amount in each bin, or knowing that a trailer full of produce to animal feed was delivered without measuring the amount. It is advantageous to use these methods in combination with other methods, such as interviews, as a complimentary source of information to national statistics.

\subsubsection{Experience from other projects}

This project was based on experience from a number of projects, notably one project carried out in 2012-13 with the same project partners and which was also financed by the Nordic Council of Ministers. One important source of information and insight was the FUSIONS research project.

The experience from these projects led to a new approach towards quantification. Statistics were found to be a good method when quantifying meat losses in the Nordic Countries because data from these countries were already systematically collected and exist at each farm because of national or EU legislation. The study also revealed differences in food losses between countries due to differences in production conditions. Therefore an aggregation into Nordic common relative side flow numbers was done to improve the quality of the side flow quantification. 
Another experience was that some interviewees found some material flows very difficult to quantify, especially harvest waste for plant field crops. The possibility of using material balance for calculating side flow was considered, but there was insufficient data. Total yields, export and import numbers could probably be found, but data on the total amount sold to consumers would be more difficult to obtain.

\subsubsection{Choice of methods in this project}

It was decided to use questionnaires and field studies as the main methods to quantify waste in some selected product groups. It was also decided to study some of the same case products as in the previous project to compare methodologies, i.e. interviews, questionnaires and field studies for carrots. Furthermore, it was decided to do similar studies for the same products in several countries in order to compare results, and how the methods worked in practice, between countries.

The previous study of primary production side flows (Franke et al., 2013) revealed that there was very little available data on harvest side flows and that farmers and agricultural experts had little knowledge about the amounts. Field studies carried out by researchers were chosen as the research method for quantifying harvest side flow amounts and hopefully give some insight into reasons for this waste.

It was decided to combine the field studies with farmers' interviews. Part of the reason for this was to compare farmers' estimates with measured quantities in order to evaluate whether farmers' estimates would be sufficient in future studies. Another reason was to get more insight into what happens at the farm site and what the real problems are.

Moreover, published data was used to scale up the results and to calculate total National side flow in primary production (see chapter 3).

\subsection{Development of methods}

During the course of the project, the selected methods were modified, adapted and tested based on experience gained in this and previous projects.

\subsubsection{Methods developed from previous studies}

Direct measurements where the method used to measure harvest side flows for two vegetable products, one cereal and one pulse product. The 
basis of the testing was published methods, but these were modified before and during the test period.

Before the project started questionnaires and interviews were developed based on previous experience, mainly in Finland and Sweden. Questionnaires were the main method used to study total side flows in primary production. They were used for two vegetable products, two pulse products, two grain products and two fish products. The questionnaires were analysed using a common template. The analyses based on statistical data was done using a similar procedure as in the previous Nordic project (Franke et al., 2013).

\subsubsection{Similar but different methods in each country}

During the development and test phase, it was decided to use similar methods for similar test products in each of the four countries. The idea was to make results in the different countries as comparable as possible so that the results would show the "real" variation in side flow amounts (and treatment, reasons, reduction possibilities) rather than reflect methodological differences.

The method should be applied in the same way while taking local conditions into account. For instance, care had to be taken to use terminology that the farmers were familiar with and to adapt to the reality the famers were facing. For example, when alternatives for side flow reasons were given, this had to be based on the real problems that farmers faced in each country.

\subsubsection{Questionnaires}

\section{Questionnaire layout and content}

Questionnaires were the main methodology used. During the project, two main types of questionnaires were tested:

- a. A simplified questionnaire developed in Sweden (Franke and Persson 2014), containing questions on respondents' roles and on side flow amounts, reasons and treatment.

- b. A comprehensive questionnaire, based on work in Finland (Hartikainen et al., 2013) containing questions on a number of issues other than the above mentioned respondents' roles, side flow amounts, reasons and treatment, economy, agricultural techniques, reduction possibilities, yield and other issues.

For details on the questionnaires, see the Technical report of this project. The main motivation for the simplified questionnaire was to make it less 
time-consuming and easier for the farmers to respond, thus hopefully increasing the response rate. In addition, some data were easy to access by the government agencies, reducing the need for additional questions outside the core questions on waste quantification. The simplified questionnaire did not contain any question on yield or cultivation area, thus making weighted means impossible. The rationale behind the comprehensive questionnaire was to gather information that allowed for a more detailed study of the side flows. One important aspect of the comprehensive questionnaire was to allow quantification using different definitions, and most importantly the FUSIONS definition and system boundaries vs. our own definition and system boundaries. This required detailed information on side flow treatment and in what part of the value chain the side flow occurred.

\section{Questionnaire distribution method}

Two main methods for distributing and gathering data were used. The most common method was to send an e-mail with introductory text and a link to a webpage with the survey software (online survey). In Finland and Denmark all questionnaires were sent by email, therefore the questionnaires were sent only to those producers who had shared their email addresses. In Sweden, all questionnaires were distributed by post because past experiences have been that this leads to a higher response rate. The respondents would have had to fill in the answers by hand and return the form by post. In Norway, Finland and Denmark, invitations to join was sent by email which contained a link to the survey webpage. Some producers in Norway did not give an email address. These producers were sent a letter containing the same information as in the email. They were given the opportunity to answer the survey online or fill it in by hand and submit it post.

Obtaining address lists was done in different ways. In Norway, the carrot and onion farmers' addresses were obtained by contacting the producer's organisations, while the wheat farmers' addresses had to be purchased by an organisation set up by the farmer's organisations to fulfil this need. In Finland, Sweden and Denmark, the address list was given out by government agencies.

The questionnaire surveys were carried out at different times of the year. For Finland questionnaires on rye, pea, carrot and onions were sent in April 2014, and the rainbow trout questionnaire was sent out in February 2015. For Sweden the carrot, onion and wheat questionnaires were sent in April-June, and the trout/char and peas in September. For Norway, carrot and onion questionnaires were sent in April-May, peas and wheat in August. Ideally, they should have been carried out when the respondents would have time to fill them out. 
All questionnaires were sent with an enclosed letter explaining the study to the respondents, with hopes that this would motivate them to answer. The letter was different from country to country. In some cases the partners had sought the support of external parties like government agencies or farming organisations, although this was not done for all cases.

As a further incentive to increase the response rate, a reward was offered in the Norwegian questionnaires: an iPad would be given to one of the respondents. No such reward was offered in the other countries. In Denmark and Sweden, this was because the government agencies sent out the questionnaires. In Finland, a few incentives were used to attract producers to respond to the questionnaire. First, it was explained that only the producers themselves could provide us with the data we were collecting (which does not exist elsewhere). Secondly, the importance of the topic was emphasised, and we stated that the producers' responses and suggestions could have an impact on making improvements. Thirdly, by answering the questionnaire the producers would also be entered into a prize draw, and they would receive a summary of the key findings of the project.

\subsubsection{Interviews}

Interviews are a method to gather data with personal contact through telephone or face-to-face. The advantage of interviews is that they are flexible and allow for more detailed insight into issues such as reasons behind side flows. However, similar to questionnaires, this method requires the farmer to have access to the necessary information. This is not always the case. For example, it might be the next part of the food chain, like a packing plant, that has the required information.

In this study interviews were chosen as a supplementary data collection method rather than a primary method. The reason being that interviewing is a very resource- and labour-intensive method, and in the case studies we found questionnaires were a better tool for quantification purposes whereas interviews were better for qualitative insights. In Finland, interviews were used before and after questionnaires - first to pilot the questionnaires and later to get experts/farmers to comment on the results of the questionnaires. Thus, while it was supplementary it was also a way to improve the questionnaires and to help interpret the results as well as getting more support for the conclusions.

Most interviews were semi-structured. The structured part of the interview contained the minimum information that we needed in relation to the topic, e.g. side waste quantity, treatment, reasons, and reduction possibilities. The second part of the interview contained more open- 
ended questions, which can lead to additional insight into the topics covered. Thus interviewing gave the same results as a questionnaire plus additional information and insight into the topics, including interesting facts that we hadn't thought to ask. Interviewing also allows for the interviewee to be guided in making estimates when he/she do not have all the relevant data.

The Technical report contains an interview guide. The guide is a result of experiences gathered in this project and experts experience, e.g. from researchers at NIBIO, the Norwegian Institute for Bioeconomy Research and from plant, animal and fish experts at the Swedish Board of Agriculture. This guide contains a list of questions, some advice on how to use the questions and explanation on why they are included. The guide is intended as a source for inspiration for future research work in the field, both for interviews and questionnaires. Not all questions are relevant for all situations, e.g. there are differences between seemingly culturally similar countries like the Nordic Countries. This project has shown the importance of adapting questionnaires to the context they will be used in, preferably using both experts and test respondents.

\subsubsection{Direct measurements}

Field studies were done to measure harvest losses for carrot, onion, wheat and field peas. In most cases, interviews were carried out to complement the information we collected from our own observations.

For each lot, several plots of a given area (e.g. $2 * 10$ meters) were marked by sticks and rope, all carrots that remained were dug out, cleaned of earth, weighed and put back in the field. It was not necessary to dig for the onions since they were already on the ground. A simple method was used in order to sample piles of product left in the field or unharvested sections of the rows. The number of piles in each field was counted, and three to four average size piles were weighed. From these average weights, the total weight of the piles was calculated. In addition, in some fields there were sections of the rows that had not been harvested. The length of these sections were measured, and the weight of the remaining onions were estimated by weighing three parts of a row and using the average weight per meter of the row to calculate the total weight of onions remaining in the field caused by the unharvested sections. Yields also had to be calculated to get the relative waste level. The yield determination could be done by asking the farmer or by measuring a sample of unharvested plots in the fields. Average side flow levels are calculated for each field, each farmer and for all farmers. 
The information gathered in the carrot, wheat and pea studies were complemented by information from questionnaires (in the field study samples) and interviews (of farmers and experts). The combination of methods gave more insight into the reasons for side flows and possible reduction measures and gave information that could be used in planning future studies and better understanding the reality behind side flow numbers. For example, the interviews gave information about structural reasons for side flows including the farmers attitudes and economic viability of utilising side flows. The role of weather and equipment for harvesting side flows was another topic that interviews shed more light on.

For wheat and peas, a distinction was made between pre-harvest waste and harvest waste. The pre-harvest loss was assessed by weighing lost/shedded seed or spikes in the field before harvest, in four parallel spots in $1 \mathrm{~m}^{2}$ delineated by a metal frame. Additionally, the samples were taken from clearly different places, e.g. plain cutting brand, turning point or balk, or from spreading channel, if these were present in the field. The total loss was assessed after harvest using the same method. Harvest waste was calculated as the difference between total losses and pre-harvest losses.

\subsubsection{Using published data}

There are many types of published data. These can include national statistics, reports on farmers' economy, waste treatment statistics, scientific reports and articles. The published data can include different information. In this study, it was used to find side flow amounts and total production amounts, the latter to calculate relative side flow amounts (side flow as a percentage of total production). One important source for this project was national statistics. Such statistics are generally available for several meat and (aquaculture) fish products. Data availability is also good for cereals, such as showing what amounts of wheat in Norway go to animal feed and human consumption.

Side flows for salmon and trout from aquaculture was calculated using a Norwegian study (Bleie and Skrudland 2014). The system borders of this study were from when the fish was put into seawater until they were slaughtered. This meant that the early part of the lifespan from hatching onwards was not included and therefore the lost biomass at this stage is expected to be very low. At the same time, questionnaire studies for rainbow trout were done in Sweden, Denmark and Finland, and in Sweden, char was included. The Norwegian study considered all side flows in primary production (according to this project's definition) except 
side flows from after slaughter to arrival at processing plant, and side flows in the early stage from hatching until when the fish are put into seawater. One major advantage with the study was that it represented a vast majority of Norwegian aquaculture production, as well as giving valuable insight into side flow reasons. The side flow was expressed as a percentage of individual dead fish compared to all individuals at the start of life. In this project, the number of individuals was recalculated to lost biomass, using average biomass amounts ( $0-3$ months: $0 \mathrm{~kg}$; $4-10$ months $0.06 \mathrm{~kg}$; 11 months to slaughter: $5 \mathrm{~kg}$ ). This was divided by the total potential production calculated by multiplying the number of individual fish by average slaughter weight. This is a theoretical analyses giving as the result the lost biomass that could potentially have be used as food. In practice there is currently no market for fish that have not reached slaughter weight, therefore one could argue that these fish do not represent a loss. However, if the fish had not died it would have been used as food and thus represented an economic value and nutritional benefit. Thus it is clear that fish which die during the rearing phase do in fact represent a loss, yet there is currently no generally accepted way of quantifying this loss.

Meat losses can be calculated using national statistics for the number of dead animals at each life cycle stage and in transport to the slaughterhouse. Similar to fish waste, the lost biomass was found by multiplying the number of dead animals at each life stage by the average weight at that stage. The relative waste was calculated as percentage of lost biomass of total potential production. 


\subsection{Strengths and weaknesses of the methods used}

\begin{tabular}{|c|c|c|}
\hline Method & Strengths & Weaknesses \\
\hline Questionnaires & $\begin{array}{l}\text { Allows for studying a large number of } \\
\text { study objects. } \\
\text { Easier to get more statistical valid results } \\
\text { than interviews and direct measure- } \\
\text { ments. } \\
\text { Less resource intensive than interviews } \\
\text { and direct measurements. }\end{array}$ & $\begin{array}{l}\text { Limited possibility to explain ques- } \\
\text { tions. } \\
\text { Often too low a response rate be- } \\
\text { cause participation is voluntary. } \\
\text { Respondents might be tempted to } \\
\text { quit before completion if the list of } \\
\text { questions is too long. }\end{array}$ \\
\hline Interviews & $\begin{array}{l}\text { Allows explanation of questions. } \\
\text { Gives greater flexibility in information } \\
\text { gathering. } \\
\text { Allows more in-depth analyses. } \\
\text { Easier to persuade people to go through } \\
\text { the whole list of questions. } \\
\text { Good for finding side flows reasons and } \\
\text { reduction possibilities. }\end{array}$ & $\begin{array}{l}\text { Very resource intensive, especially } \\
\text { face-to-face. } \\
\text { Limits the maximum number of study } \\
\text { objects and thus statistical validity. }\end{array}$ \\
\hline Direct measurements & $\begin{array}{l}\text { Direct observation makes high precision } \\
\text { possible. } \\
\text { Easy to standardise study, can gives more } \\
\text { precise results than other methods. } \\
\text { Can be used to "calibrate" farmers' esti- } \\
\text { mates. }\end{array}$ & $\begin{array}{l}\text { Very resource demanding and time- } \\
\text { consuming, thus difficult to get a sta- } \\
\text { tistically significant end result if the } \\
\text { number of actors and variability is } \\
\text { high. } \\
\text { May interfere with farming activities. }\end{array}$ \\
\hline \multirow[t]{2}{*}{$\begin{array}{l}\text { Using published data and } \\
\text { published side flow study } \\
\text { results }\end{array}$} & $\begin{array}{l}\text { Requires few resources. } \\
\text { In some cases, e.g. for data from national } \\
\text { statistics, a large percentage of the popu- } \\
\text { lation is covered. }\end{array}$ & $\begin{array}{l}\text { Often not ready to be used as such. } \\
\text { Need to modify the data and possibly } \\
\text { combine it with other data. }\end{array}$ \\
\hline & $\begin{array}{l}\text { Often required by law to report; data ex- } \\
\text { pected to be of high quality. }\end{array}$ & $\begin{array}{l}\text { Little detail is given on other issues } \\
\text { such as side flow treatment, side flow } \\
\text { reasons, or possible side flow reduc- } \\
\text { tion. }\end{array}$ \\
\hline
\end{tabular}

\subsubsection{Questionnaires}

The response rate from the questionnaire study compared to the required coverage of a certain population shown in Appendix 1 shows that the sample sizes of the questionnaires were not big enough. The difference between required sample size and realised sample size was quite large in most cases.

Overall the data are inadequate to calculate the uncertainty. The standard deviation in each result is high. It is unknown how much of this high deviation is caused by "real" differences in side flows, how much is based on the uncertainty from farmers not knowing exactly how much side flow they have (farmers do not generally keep a record on the amounts of side flows, end-uses of the side flows or reasons for the side flows), and how 
much is caused by the methodology. It is not possible to state how large the uncertainty of the results are, but they are likely to be high.

Our studies did reveal problems with the questionnaires as they were used. One problem was that the respondents did not have access to the information we wanted. One example concerns the Norwegian wheat study (simplified questionnaire) and the question: "How much of your total harvest was wasted (not used for food)". The farmer had to choose between different alternatives (e.g. in the field, at harvesting, at transport) but could also write in his own answer. Many gave illogical answers (e.g. answers adding up to $100 \%$ ), very few answers or they just wrote zero for all their answers. The first problem could be explained if farmers were not sure at what stage the side flow occurs; the low answers (e.g. $0.01 \%$ ) could be explained by confusion between percentages and ratios (a ratio of 0.01 equals 1\%); and the "zero" answers could mean that there is no side flow or that the respondents did not have this information.

The questions on side flow treatment asks for amounts (as a percentage of total side flows) of side flow for each treatment. The question relating to reasons for side flow was asked in the same way: for each reason a certain percentage of total side flow was asked for. If all questions had been related to absolute amounts then it would have been possible to cross-check side flow amount results.

This study also revealed problems with the larger questionnaires used in several studies. In several studies the questions were difficult to understood, such as the question in the Danish carrot study regarding at which step the side flow was sorted out. It seems the material balance question ("end use of carrots") was a better source for information on side flow amounts, and the question on where it is sorted out was more directed at explaining side flow reasons.

\subsubsection{Interviews}

The interviews were useful for quality control purposes and to shed light on results from others studies. For example, in the Swedish trout questionnaire the interviews highlighted how some questions were ambiguous or difficult to interpret. In the question about what proportion of fish died or were discarded during production, a number of causes for loss or steps in the production process where loss may have occurred were given. Some of these can be interpreted as alternative descriptions of the same production step/sub-stage. 
The interviews worked well for the purposes mentioned. The wheat questionnaire in Norway was based on a simplified version of Swedish questionnaire. It was translated and sent out without follow-up interviews to check whether it was understood correctly. The answers and feedback (in the questionnaire and in e-mails) showed that some questions were easily misunderstood for the farmers, and the questionnaire should have been modified before being sent out.

In most cases the questionnaires were sent to farmers by e-mail before the study, and in some cases to agriculture experts. The feedback was used to modify the questionnaire, but the feedback and answers from the questionnaire revealed other problems that might have been resolved using an interview because interviews allow more indepth reflections on certain issues.

The interviews provided a lot of useful information that was useful when interpreting the results from questionnaires and direct measurement. Interviews could also be used for quantification if populations had been lower. In such cases, it would have been necessary to standardise the structured section to get comparable results.

\subsubsection{Direct measurements}

This method was used in three countries for measuring harvest side flow because it was the only method that was found to be useful for this application. Our experience has shown that this research method is very resource intensive, especially when using external people to do the measurements, as we did. Due to this, we could only do a few measurements for each product. At the same time, high variability in side flow amounts was observed, and side flow product was often distributed very unevenly across each field. The research also indicated that weather conditions at harvest time was very important. Taken together, these facts indicate that there is a high uncertainty of the harvest side flow results. In order to reach statistically significant results a large number of fields should be measured, which makes it less realistic to carry out the study. The studies also revealed some practical difficulties with the method. This method is difficult to plan for due to unpredictable weather and because farmers might change plans at short notice, therefore it requires researchers to be very flexible. It can also be a challenge for the safety of those carrying out the measurements if done right after harvesting, as there is often a lot of vehicles and equipment moved around the fields at harvest time.

Despite all these disadvantages, direct measurements are probably the best method to study harvest waste because of lack of alternatives. 
The harvest side flow amounts estimated by farmers and gathered from questionnaires in this project, as well as interviews from the previous project, shows in general far lower numbers than the field studies. This indicates that farmers systematically underestimate harvest side flow amounts.

\subsubsection{Published data and side flow studies}

The calculation of side flow for cereals was based on questionnaire results and field studies, even though statistical data existed for the amount of cereals going to animal feed and human consumption (for a number of years) in several countries. This was chosen because statistical data excludes harvest losses and other losses before the cereal is sold on. Furthermore a high share of the production was intended for animal production (e.g. most of wheat production in Denmark is intended for animal feed) so it was not possible to get good results based on cereal statistics. The statistical data were not used for quantification because it did not differentiate whether the crop was grown with the intention of selling it as feed (in which case there is no side flow) or for human consumption (in which case the amount used for animal feed was side flow). Another reason is that the data contain little information on reasons for side flow and potential reduction possibilities, as well as other information that could be useful, such as size of farms or geographical location.

The data showed large variability from year to year, probably due to climate conditions. This fact would not have been discovered if a side flow study would have been done for only one year. This is important information for the users of the data, especially when data are aggregated across several product groups and several steps of the value chain. Thus, statistical data often has a big advantage because it is often collected over several years. Another big advantage is that it often covers a large part of the studied population, probably because giving information to the government is often mandatory, whereas answering scientific questionnaires are mostly voluntary. The cereal case is therefore a good example of the potential advantage and disadvantage of using statistical data.

The meat and fish side flow study results, which were calculated from statistical data and one side flow study, are assumed to be of high quality and low uncertainty. However, there is a potentially large uncertainty introduced when these numbers are calculated for one country and extrapolated to other countries. For pork side flow, the side flow rates which were shown differ little between Nordic Countries in 
this study, whereas in the previous study the difference was larger. The weight of each individual animal or fish at the time of death was not known. When calculating biomass side flow from numbers of individual animals or fish, average weights were used. This introduced uncertainty into the calculations, but it was not possible to calculate the magnitude of uncertainty from these information sources (national statistics and side flow study). It can also be argued that the fish or animals, at the time of death, could not be included as side flow because they would not be suitable as raw material for products that could be sold on the market (disregarding the cause of death). However, this argument does not reflect the fact that any animal or fish which dies before reaching slaughter weight will indeed reduce the amount of food available. However, it might be a good idea to present separate figures for side flows occurring before the fish or animal is ready for slaughter in order to address the limited marketability of products from fish and animals before they reach slaughter weight.

Scientific publications were also used as a source of information for this study. A limitation on the use of such studies is that there is no standardised way of calculating side flows, which means that the results may vary a lot from study to study, not only due to real differences but also due to methodology differences.

\subsection{Research method recommendations}

For this project, research methods for side flow studies were chosen, adapted and tested. Based on our experiences from this process we can give some recommendations for future studies. The following is a summary of these recommendations. 
Table 13: Method recommendations

\begin{tabular}{ll} 
Method & Recommended application and adaptation \\
\hline Questionnaires & $\begin{array}{l}\text { Recommended for studying large volumes, e.g. open field crops, eggs and milk and } \\
\text { some vegetables and fruits. } \\
\text { Should contain open questions to shed light on results. } \\
\text { Recommended as a supporting tool for all other methods. } \\
\text { Recommended for studying side flow reasons and reduction possibilities. } \\
\text { Can be used as a separate tool when the number of interviewees is relatively small. } \\
\text { Possible cases include greenhouse crop producers, transport companies, storage fa- } \\
\text { cilities vegetable pack houses. } \\
\text { Good for measuring harvest waste. } \\
\text { Can also be used for measuring other side flows such as storage waste, but the } \\
\text { method has serious limitations if external people take the measurements. If the in- } \\
\text { volved actors can be persuaded to do the measurements, then this method might } \\
\text { be the preferred methods for other flows where no recorded data exists. }\end{array}$ \\
$\begin{array}{l}\text { This approach is recommended whenever data availability is high, e.g. for most } \\
\text { meat products, and when they can be used considering the definitions of side flow } \\
\text { side flow results }\end{array}$ \\
$\begin{array}{l}\text { and primary production. } \\
\text { The data and results must be quality checked. } \\
\text { It will often be necessary to gather information elsewhere to understand the num- } \\
\text { bers better and to use the numbers in calculations. }\end{array}$
\end{tabular}

\subsubsection{Questionnaires}

Questionnaires should be adapted to the product, geographical region, production technology and other important issues. One such additional issue is the length of the questionnaire, which should be balanced against the need for information. Long questionnaires probably mean lower response rates, but including several questions may be crucial for the study's success. Questionnaires should ideally be set up so that a farmer gets immediate feedback if the input value is wrong, e.g. if percentages do not add up to $100 \%$ or the answer is given in kilograms instead of tonnes. The questionnaire should also give the possibility to cross-check answers, such as asking for the amount of side flows in absolute amount (e.g. tonnes) and for how side flows are treated in absolute amounts (e.g. tonnes).

It is highly recommended to pilot-test the method with potential respondents before it is used on larger populations; an interview is probably the best format for collecting detailed feedback. It is important to use terminology that the respondents are familiar with and avoid terms that respondents use differently or have objections against. This was one important reason for using "side flow" rather than "food waste" in this study. Farmers did not agree that e.g. product sent to animal feed should be considered as "wasted". 
The time of year that the study takes place is important. Farmers should be contacted when they are less busy, such as at the beginning of the year. In order to motivate the farmers to participate it is advised to contact farmer's associations, government agencies and other relevant organisations to get their approval and even cooperation. This support should be stated in the accompanying letter.

\subsubsection{Interviews}

Interviews can be used for the quantification of side flows, quality checks of methods and to gain deeper insights into reasons behind side flow, how they are treated and how side flow amounts can be reduced or better utilised.

In most cases, the number of involved actors in primary production is high. In these cases, it is better to use interviews for qualitative insights rather than quantitative purposes, such as quantifying side flows. The interviews could also be used for quantitative purposes (if populations are high), e.g. to understand how respondents think when doing quantifications, but only as a secondary purpose. The interviewer should be aware that respondents' time may be limited and should therefore ask the most important questions first.

\subsubsection{Direct measurements}

Measurements should be done soon as soon as possible after harvest. Ideally, the researchers should observe the harvesting to get a better understanding of how side flows are created. It can also give them a better of idea of where to choose the test areas. In order to find out the relative side flow amount, data on the total yield are needed. This can be done by asking for the farmers' estimates, or by testing the yield in small test plots, to check the farmers' estimates.

Weather conditions during harvest are important. Bad weather can cause a significant increase in side flow amounts. The weather during the study should reflect the "average" weather of the harvest season. It is also necessary to look beyond the chosen test plots. If there are piles of products in the field or unharvested rows, they must also be sampled. Of course, the methods for placing the test plots must also be chosen carefully, and sometimes areas with piles or empty areas have to be excluded.

If the measurements are done during the harvest, it can be challenging because of health and safety issues. It is recommended to have at least two, preferably three or more people doing the tests to ensure safety. 


\subsubsection{Published data and side flow studies}

Using statistical data and results from side flow studies are the preferred approach in most cases where such data exists. Even though the data might be national statistics or from peer-reviewed studies, it might not have the quality needed for a side flow quantification study.

In many cases, the data must be modified before being used and/or combined with other data to give the preferred results. The use of statistical data on side flows generally has a high potential for giving reliable and precise side flow quantity results based on entire populations. The potential cannot always be realised, e.g. for government cereals statistics where wheat intended for food and feed are mixed. One major disadvantage of such statistical data is that it often contains little information on side flow treatment, side flow reasons and possible reduction measures. Such data must be gathered elsewhere, e.g. through interviewing experts, government officials, farmer organisations and, of course, the farmers, transport companies and slaughterhouses. 


\title{
Conclusions and recommendations
}

\author{
Use side flow for a holistic approach in primary \\ production
}

Several definitions of food losses and food waste exist in literature and quantifications studies, for example the FUSIONS definition for food waste. Food waste does not include all primary production and therefore a new term was developed - side flow - which incorporates animal rearing and products that end up as animal feed (but originally was planned to be food) although, unlike the FUSIONS definition, inedible parts are excluded. It would have been very interesting to study side flows during the growth phase of plants as this could give insight into reasons for side flows. Such topics are difficult to study because of technical reasons and high resource intensity, but it is possible, as demonstrated in the Finnish field study for wheat.

Depending on the scope of the quantification, various terms may be used. The new term side flow is preferable when understanding the amount and driving forces of the flows of food waste and production losses in primary production from a food security point-of-view. In the future, losses during the growing phase of plants could and should be added to the side flow definition to get a more complete picture of food waste in primary production.

\section{0,000 tonnes of side flows and 330,000 tonnes of food waste}

An attempt to estimate the total Nordic amount of side flows resulted in 0.8 million tonnes and 0.1 million tonnes from animal rearing. This corresponds to 3.2 and $0.5 \%$ of the total production in the primary production sector. Using the more narrow food waste and primary production definitions proposed by FUSIONS, the food waste amount was estimated as 0.33 million tonnes, or $1 \%$ of the total production. The main reason for 
the difference is that food which ends up as feed are included in the side flow amounts, but not in the food waste definition.

It is important to note that the side flow and food waste amounts are rough estimates of the Nordic figures and do not consider country specific circumstances. Thus there is a need for a better understanding of productand country-specific side flow and food waste amounts to improve the current estimates.

\section{Use more than one method to quantify side flow}

The methods used in the case studies to collect data were questionnaires, direct in-field measurements and interviews. The suitability of each method depends on the product and the needs of the study. Thus we cannot recommend one single quantification method.

Questionnaires are the recommended method in cases where side flow data are known by the primary producers, but are not publicly available, e.g. for most plant crops. Questionnaires must be adapted to the product studied, technology used, respondents (mostly farmers), organisation of the production (who does what), context and other factors.

Interviews are the recommended method when the number of participants is small. These are a valuable tool to support other methods like questionnaires, field studies and open-source data. This method works well to get a better understanding of side flow reasons and other issues connected with side flow.

Direct measurement of harvest side flow is the recommended method to use in cases where side flows have not been measured before. In cases where the variability is high, e.g. for field crop harvest side flow, a large number of measurements is necessary in order to attain statistically valid results.

Published data is a good method for calculating side flow where statistical data is available, e.g. for cereal or meat side flow. However, in most cases more information is required for a quantification study. 


\section{References}

Andersson, S. 2013 Tomatens öde - en kartläggning av matsvinn i primär produktionen. Lunds Universitet, Sweden. Examensarbete för masterexamen.

Balance Sheet for Food Commodities Finland 2016 http://stat.luke.fi/en/ balance $\% 20$ sheet $\% 20$ for\%20food\%20commodities

Bleie H. and Skrudland A (2014). Tap av laksefisk i sjø. Rapport fra Mattilsynet. August 2014.

Breen \& Vengnes 2016 Personal communication 14.3.2016 Øyvind Breen \& Mari Vengnes, Norwegian Agriculture Agency

Cederberg, C., Sonesson, U., Henriksson, M., Davis, J., \& V, S. 2009 Greenhousegas emissions from production of meat, milk and eggs in Sweden 1990 and 2005. Göteborg: SIK rapport 792, SIK- Institutet för Livsmedel och Bioteknik, ISBN 798-91-7290-284-8.

Cereals Balance Sheet Finland 2016 http://stat.luke.fi/en/cereals-balance-sheet Cereals Balance Sheet Sweden 2016

Christensen I. 2015 Personal communication in November 2015 with Inger Christensen at Grön Kompetens

Christiansson 0. 2015 personal communication in November 2015 with Ola Christiansson at Nordic Sugar in this project: represents results of Sweden Nordic Beat Research

Davis, J., M, W., V, S., A, E., Cederberg, C., Sonesson, U. 2011 Emissions of Greenhouse Gases from Production of Horticultural Products- Analysis of 17 products cultivated in Sweden. Göteborg: SIK- The Swedish Institute for Food and Biotechnology.

Det Danske Fjerkræråd 2013 Årsberetning 108 pp (In Danish and English)

Enemark, P.S. 2015 Laveste kodødelighed i ti år. http://www.seges.dk/ Nyheder/lavestekodoedeligheditiaar.htm

FAOSTAT 2016 Production http://faostat3.fao.org/download/Q/*/E

Finnish Fisheries Statistics 2012 http://www.rktl.fi/www/uploads/pdf/ uudet\%20julkaisut/taskutilasto2012_netti.pdf

Finnish Fisheries Statistics 2014 http://www.rktl.fi/www/uploads/ Tilastot/tasku2014.pdf

Franke, U., Einarson, E., Andrésen, N., Svanes, E., Hartikainen, H., Mogensen, L. 2013 Kartläggning av matsvinnet I primärproduktionen. Udgivet af Nordisk Ministerråd. 87 pp (In Swedish with UK summary). http://dx.doi.org/10.6027/TN2013-581

Franke and Persson 2014, A simplified questionnaire developed by Ulrika Franke and Jörgen Persson within this project.

Gustavsson J., Cederberg C., Sonesson U., Emanuelsson A., 2013 The Methodology of the FAO study: "Global Food Losses and Food Waste-extent, causes and prevention"-FAO, 2011. Göteborg: SIK.

Hartikainen Hanna, Miia Kuisma, Marja Pinolehto, Raija Räikkönen, Helena Kahiluoto 2014 Food waste in primary production and food processing (Finnish) http://jukuri.mtt.fi/handle/10024/485067 Marknadsöversikt potatis till mat och 
stärkelseproduktion 2015 http://www2.jordbruksverket.se/ download/18.17f5bc3614d8ea10709e5311/1432820127276/ra15_9.pdf

HLPE 2014 Food losses and waste in the context of sustainable food systems A report by The High Level Panel of Experts on Food Security and Nutrition - June 2014. http://www.un.org/en/zerohunger/pdfs/HLPE_FLW_Report-8_EN.pdf

Hobson, R., Bruce, D. 2002 PM-Power and machinery: Seed Loss when Cutting a Standing Crop of Oilseed Rape with Two Types of Combine Harvestrer header. Biosystems Engineering vol 81 (3), ss. 281-286.

Hollstedt, S. 2011 Äggkvalitet kopplat till produktion, ekonomi och djurvälfärd hos svenska värphöns. Uppsala: Examensarbete 30 p, SLU, Institiutionen för husdjurens utfodring och vård.

House to Homestead (2011) Chicken Math - How Much Meat is in a Whole Chicken? http://www.housetohomestead.com/2011/03/chicken-math-how-much-meat-isin-a-whole-chicken/

Jordbruksverket 2006 Metodbeskrivning EAA Ekonomisk kalkyl för jordbrukssektorn. Jönköping: Sveriges officiella statistik, Jordbruksverket.

Jordbruksverket 2009 Ekonomi-Kalkyler för odling av grönsaker på friland, Jordbruksinformation 25. Jönköping: Ascard, J; Håkansson, B; Söderlind, M .

Jordbruksverket 2015 Marknadsöversikt potatis till mat och stärkelseproduktion http://www2.jordbruksverket.se/download/18.17f5bc3614d8ea10709e5311/1432820127276/ra15_9.pdf

Jordbruksverket 2016 Matsvinn inom ägg- och matfågelproduktion http://www2.jordbruksverket.se/download/18.2e6f24cf152e919a4a3808f/1455613813250/ovr379.pdf

Jordbruksverkets statistikdatabase 2012 Slakt av fjäderfä vid slakteri år 2005-2011, Sveriges officiella statistik. Hämtat från www.jordbruksverket.se:http://statistik.sjv.se

Ländell, G., \& Wahlstedt, G. 2012 (den 6 november 2012). Svinn inom primärproduktionen, mail konversation. (D. Persson, Intervjuare)(Cf Frankes etal., 2013).

Mattsson, C. 2014 Vi slänger frukt och grönsaker i onödan - Varför? Jordbruksverket. Rapport 2014:5.

Møller, Hanne; Hanssen, Ole Jørgen; Svanes, Erik; Hartikainen, Hanna; Silvennoinen, Kirsi; Gustavsson, Jenny; Östergren, Karin; Schneider, Felicitas; Soethoudt, Hans; Canali, Massimo; Politano, Alessandro; Gaiani, Silvia; Redlingshöfer, Barbara;

Moates, Graham; Waldron, Keith; Stenmarck, Åsa, 2014 Standard approach on quantitative techniques to be used to estimate food waste levels, Fusions Report, $108 \mathrm{p}$

Norwegian Agriculture Agency 2016 www.landbruksdirektoratet.no

Norwegian Statistics Agency 2016 https://www.ssb.no/statistikkbanken/

Olsson, Marie and Andersson, Staffan and Ekelund Axelson, Lena and Larsson, Gunnel 2011 Kvalitet och tillväxt för lökprodukter, Sveriges lantbruksuniversitet. Landskap trädgård jordbruk: rapportserie ; 2011:45 http://pub.epsilon.slu.se/9397/

Östergren Karin, Jenny Gustavsson, SIK-The Swedish Institute for Food and Biotechnology, Sweden; Hilke Bos-Brouwers, Toine Timmermans, Wageningen UR, Netherlands, Ole-Jørgen Hansen, Hanne Møller, Ostfold Research, Norway; Gina Anderson and Clementine O'Connor, BIO for Deloitte, France; Han Soethoudt, Wageningen UR, The Netherlands; Tom Quested, Sophie Easteal, WRAP, United Kingdom; Alessandro Politano, Cecilia Bellettato, Massimo Canali, Luca Falasconi, Silvia Gaiani, Matteo Vittuari, University of Bologna, Italy; Felicitas Schneider, BOKU University, Austria; Graham Moates, Keith Waldron, Institute of Food Research (IFR), United Kingdom; Barbara Redlingshöfer, French National Institute for 
Agricultural Research (INRA), France 2014 FUSIONS Definitional Framework for Food Waste, Full Report, 3 July 2014 http://www.eu-fusions.org/ index.php/publications

Raines C. R. (2015) The butcher kept your meat? by Dr. Christopher R. Raines, Assistant Professor, Department of Dairy \& Animal Science, The Pennsylvania State University http://articles.extension.org/sites/default/files/ The_Butcher_Kept_Your_Meat.pdf

Raundal, P., Nielsen, J., Flagstad, P. 2015 Kalvedødelighed i Danmark. https:// www.landbrugsinfo.dk/Kvaeg/Tal-om-kvaeg/Sider/Kalvedoedelighed.aspx Statistics Denmark 2016 http://www.statistikbanken.dk Norwegian Statistics Agency 2016 https://www.ssb.no/statistikkbanken/ SCB 2016 Statistiska Centralbyrån http://www.scb.se/

Strid, I., Eriksson, M., Olsson, M. \& Andersson, S. 2014a Svinn av isbergssallat i primärproduktionen och grossistledet i Sverige. Jordbruksverket. Rapport 2014:06.

Strid, I., Röös, E. \& Tidåker, P. 2014b Förluster av svenskt nötkött inom primärproduktion och slakt. Jordbruksverket. Rapport 2014:07.

Svanes E. 2015 personal communication

Terry Leon A., Dr. Carlos Mena, Adrian Williams, Nigel Jenney, Peter Whitehead 2011 Fruit and vegetable resource maps, Mapping fruit and vegetable waste through the retail and wholesale supply chain, Cranfield University, WRAP http:// www.wrap.org.uk/sites/files/wrap/Resource_Map_Fruit_and_Veg_final_6_june_2011.fc479c40.10854.pdf

WRI 2015 Food Loss and waste Protocol, DRAFT as of March 20, 2015 FLW Protocol Accounting and Reporting Standard (FLW Standard) PARTS I through III: I. GENERAL INFORMATION, II. PREPARING TO QUANTIFY (WHY AND WHAT), III. IMPORTANT CONCEPTS FOR QUANTIFICATION (HOW) http://www.wri.org/ our-work/project/global-food-loss-and-waste-measurement-protocol/documentsand-updates\#project-tabs 



\section{Sammanfattning}

Detta projekt har resulterat i ett förslag på terminologi och metoder för framtida studier av förluster och svinn inom primärproduktionen. Projektet har också resulterat i ett första försök att mäta svinn och förluster i primärproduktionen i de nordiska länderna, Danmark, Finland Norge och Sverige. Detta var en pionjärstudie som kräver vidare förbättringar, eftersom det finns stora osäkerheter i de data presenteras.

\section{Ett projekt med flera syften}

Ett syfte med detta projekt har varit att testa lämpliga metoder för insamling av data på förluster och svinn från primärproducenter i de nordiska länderna. Ett annat syfte var att uppskatta mängderna förlusterna svinn i primärproduktionen i de nordiska länderna. För att samla in data och kvantifiera förluster och svinn inom primärproduktionen har det varit nödvändigt att noga gå igenom de definitioner som finns, och eventuellt introducera nya, mer användbara termer. Av denna anledning har projektet handlat både om att definiera begrepp, utveckla metoder och mäta data.

\section{Helhetssyn på primärproduktionen}

Detta projekt har fokuserat på primärproduktionen i de nordiska länderna Danmark, Finland, Norge och Sverige. För att skapa en heltäckande bild av förluster och svinn i primärproduktionen, gjorde vi en litteraturstudie och ett flertal fallstudier. Inom metodutvecklingen studerade vi sju produkter: morot, lök, vete, råg, gröna ärtor, gula ärtor och odlad regnbåge/röding.

Med primärproduktion menar vi i detta sammanhang lantbruk och trädgårdsodling, men också vilda bär, jakt, fiske och fiskodling. För att få en helhetssyn på primärproduktionen har vi även mätt förluster som uppkommer inom djuruppfödningen. För att få ytterligare helhetssyn skulle även själva odlingen av växter ingå i studien, men på grund av begränsade resurser i projektet valde vi bort den delen. 
De valda systemgränserna i projektet är:

- Odlade grödor, frukt och bär som är mogna att skördas, vilda frukter och bär som är mogna att skördas, tama djur från födsel, och odlad fisk från kläckning, vilda djur eller fiskar vid fångst, mjölk från mjölkning och ägg från värpning.

- Primärprodukter innan de går in i nästa steg av livsmedelskedjan (slakt, detaljhandel eller bearbetning).

\section{Sidoflöde - ett nytt begrepp}

Vi har infört begreppet sidoflöde för att försöka fånga de flöden av svinn och produktionsförluster i primärproduktionen som var tänkta att ätas av människor men som inte går in i livsmedelskedjan. Med sidoflöde menar vi:

- Primärprodukter som är avsedda att konsumeras av människor. Därför ingår planerad foderproduktion inte i definitionen.

- De delar av primärprodukterna som är avsedda att ätas av människor. Skal och ben ingår alltså inte i definitionen.

\section{En jämförelse mellan olika termer}

Vi har gjort en jämförelse av tre olika termer, utvecklade inom tre olika initiativ:

- Sidoflöde - begreppet har introducerats i detta projekt.

- Food waste (matavfall) - används inom EU-projektet FUSIONS.

- Food Losses and Waste (livsmedelsförluster och matsvinn) används av forskningsinstitutet WRI.

Vilken av de tre som är att föredra beror på avsikten med undersökningen. Det nya begrepp sidoflöde används med fördel för att fă en uppfattning av mängderna och orsaken till matsvinn och produktionsförluster i primärproduktionen från ett livsmedelsförsörjningsperspektiv. Vare sig WRI eller FUSIONS inkluderar uppfödning av djur (eller odling av växter) i sitt undersökningsområde. 


\section{Mätmetoder}

Metodutvecklingen gjordes med hjälp av fallstudier av de sju valda produkterna: morot, lök, vete, råg, gröna ärtor, gula ärtor och odlad regnbåge/röding. De metoder som användes i fallstudierna var enkäter, intervjuer, fältmätningar och publicerad data. Vilken metod som är mest lämplig beror på vilken produkt som ska mätas och vad studien syftar till. Vi rekommenderar därför inte en specifik mätmetod.

Enkäter rekommenderas när primärproducenten har kunskap om sidoflödena, men dessa ingår inte i någon offentlig statistik, t.ex. för växtodling.

Intervjuer rekommenderas när antal deltagare i undersökningen är liten. Intervjuer fungerar bra som komplement till andra metoder och bidrar till en bättre förståelse för orsakerna till sidoflöden.

Fältmätningar av skördeförluster rekommenderas då mätningar av sidoflöden inte har gjorts tidigare. I de fall det är vanligt med stora variationer i sidoflöden, som t.ex. vid odling på friland, behövs flera mätningar för att säkerställa statistiskt pålitliga resultat.

Publicerad data är en bra metod för att beräkna sidoflöden där det finns tillgänglig statistik för produkterna. Det går t.ex. att hitta statistik på sidoflöden vid spannmålsodling och djurproduktion. Ytterligare information är dock oftast nödvändig för att kunna göra en kvantitativ studie av sidoflödena.

\section{Mängder sidoflöde och matavfall}

Med hjälp av de definitioner och systemgränser vi arbetat fram inom projektet gjorde vi en grov uppskattning av den totala mängden sidoflöde inom primärproduktionen i Finland, Sverige, Norge och Danmark. Dessutom beräknade vi mängden matavfall inom primärproduktionen i de fyra länderna genom att använda FUSIONS definitioner och system gränser. Sidoflödes- och matavfallsuppskattningarna baseras på våra studier kombinerat med befintlig statistik och publikationer.

Den totala nordiska mängden sidoflöde inom primärproduktionen uppskattas till ca 0,8 miljoner ton och ytterligare 0,1 miljoner ton som uppkommer inom djuruppfödningen. Detta motsvarar 3,2 respektive 0,5 procent av den totala produktionen av 24 miljoner ton ätbara produkter. Om vi använder oss av den definition som föreslås av EU-projektet FUSIONS, beräknas mängden matavfall till 0,33 miljoner ton eller $1 \%$ av primärproduktionen. Den största skillnaden mellan dessa båda definitioner 
är att produkter som är tänkta som livsmedel, men som i stället blir djurfoder ingår i definitionen för sidoflöden, men inte i FUSIONS definition av matavfall. Dessutom omfattar FUSIONS definition även oätliga delar (t.ex. skal och ben) av sidoflödet, medan vi utesluter dessa delar i vår definition. Viktigt att notera är att det finns ont om tillgänglig data för sidoflöden och matavfall från primärproduktion och osäkerheten i de data vi har fătt fram är väldigt stor. Detta gör att våra beräkningar bör ses mer som en indikation än som en absolut sanning.

Det är viktigt att notera att den uppskattade mängden nordiska sidoflöden och matavfall är grova uppskattningar och hänsyn har inte tagits till de olika förutsättningar som finns i varje land. Det finns därför ett behov av att bättre förstå dessa olika förutsättningar för att kunna göra säkrare uppskattningar av mängderna i framtiden. 


\section{Appendix: Uncertainties of the results}

\section{Two major issues limit the use of the results of the questionnaires.}

The first issue is that the sample sizes were much smaller than the desired sample sizes. We tested the required sample sizes using the following equation which defines the required sample size:

$$
n \geq \frac{\tau^{2}}{\operatorname{var}[\bar{x}]^{2+} \frac{\tau^{2}}{N}}
$$

Where $\mathrm{n}=$ the sample size, $\tau^{2}=$ population variance, $\operatorname{var}[\bar{x}]=$ variance of the sample mean, and $\mathrm{N}=$ population size. Additionally we assumed that:

$$
\operatorname{var}[\bar{x}]=\left(\frac{L_{0}}{2 u_{1-\alpha / 2}}\right)^{2}
$$

Where $L_{0}=$ predetermined length of the confidence interval, $\alpha=$ precision (e.g. 5 pct. uncertainty) of the confidence interval. We set the maximum width of the 95 pct. confidence interval to be \pm 1.26 percentage points (corresponding to a deviation of no more than 10 pct. from the sample mean). Thus, $L_{0}=1.26, u_{1-\alpha / 2}=1.96$.

As the base for the calculation of the sample variance, we used the question on amount of side flow (Table 1: standard deviation). Additionally, we made the assumption that the number of farmers who were sent an e-mail made up the whole of the population $(\mathrm{N})$. The results of the desired sample sizes are presented in Table 2. The table shows that due to the high variances of the amounts of side flows the sample sizes of the questionnaires are far from the desired sample sizes.

Table 1: Sample sizes and desired sample sizes

\begin{tabular}{lrrrrrr} 
& Carrot & Onion & Green pea & Field pea & Rye & Rainbow trout \\
Sample size $\mathrm{n}$ & 27 & 26 & 37 & 28 & 206 & 13 \\
Desired sample size & 258 & 232 & 493 & 361 & 757 & 41 \\
\hline
\end{tabular}


The second issue is that the farmers generally did not keep a record on the amounts of side flows, end-uses of the side flows or reasons for the side flows. Therefore, their responses were mainly based on assumptions and not on actual records.

Overall, while keeping in mind the two main issues that limited the usefulness of the results, this should not stop us from considering the results to be a first attempt on the issue. However, one should not make assumptions based on these results. In future studies there is need to increase the samples in order to present the results as statistically significant averages. For now, the results have shown us that there are many issues that affect the amounts, end-uses and causes of side flows. Therefore there are probably numerous solutions to reduce side flows and find more efficient end-uses for them. 
Nordic Council of Ministers

Ved Stranden 18

DK-1061 Copenhagen K

www.norden.org

\section{Food losses and waste in primary production}

This project has resulted in a suggested definitional and methodological framework for future food waste studies in primary production. It has also resulted in a first attempt to quantify food waste in primary production in the Nordic countries. The project was focused on primary production in the Nordic countries of Denmark, Finland, Norway and Sweden.

One purpose has been to test adequate methods for collecting data on food losses and waste from primary producers in the Nordic countries. Another purpose was to estimate the amount of food losses and waste in primary production in the Nordic Countries. In order to collect data and quantify food losses and waste in primary production it was necessary to work on these definitions or possibly introduce new, more useful terms. Thus this project involved defining terms, developing methodologies and quantifying data.

TemaNord 2016:529

ISBN 978-92-893-4609-2 (PRINT)

ISBN 978-92-893-4610-8 (PDF)

ISBN 978-92-893-4611-5 (EPUB)

ISSN 0908-6692

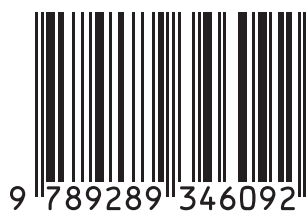

